\title{
Acute coronary syndrome - bleeding, platelets and gender
}

\section{Anna Holm}

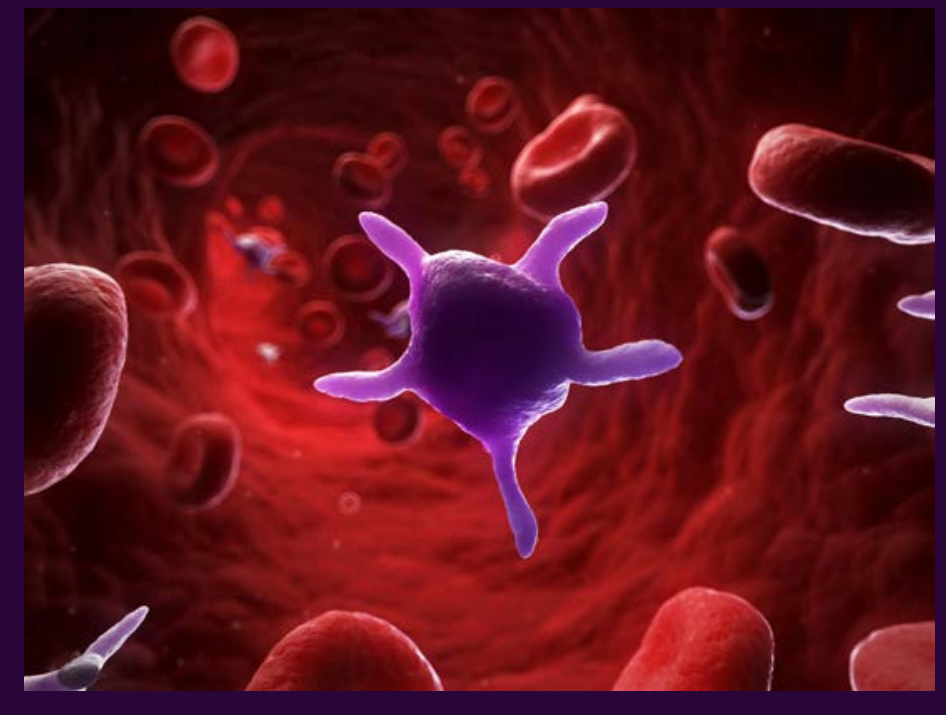


Linköping University medical dissertations, No. 1654

Acute coronary syndrome

- bleeding, platelets and gender

Anna Holm

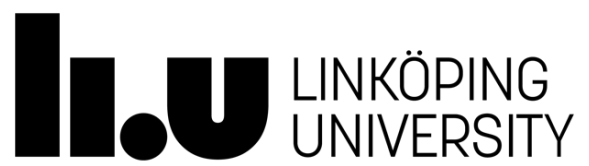

Department of Medical and Health Sciences

Linköping University, Sweden

Linköping 2019 
(c)Anna Holm, 2018

Cover picture:

Activated platelet and red blood cells.

Reprinted with permission from IBL picture agency.

Published article has been reprinted with the permission of the copyright holder.

Printed in Sweden by LiU-Tryck, Linköping, Sweden, 2018

ISBN 978-91-7685-165-4

ISSN 0345-0082 
To Jonas and Ellen

"You may see me struggle but you never see me quit"

/ Paulo Coelho

”Det finns saker här i livet som man måste göra fast man inte vill" /Pappa 



\section{CONTENTS}

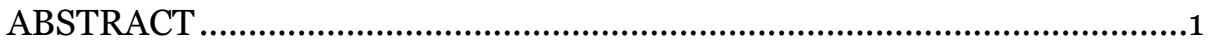

POPULÄRVETENSKAPLIG SAMMANFATTNING ................................... 3

LIST OF PAPERS …………………………………............................... 5

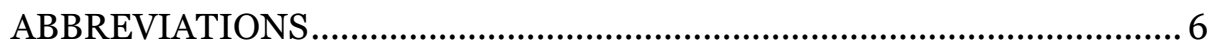

AIM

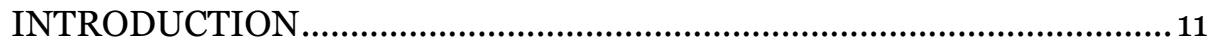

BACKGROUND.....................................................................................13

Acute coronary syndrome, definition and antiplatelet treatment ........13

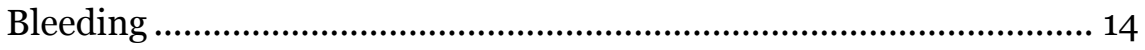

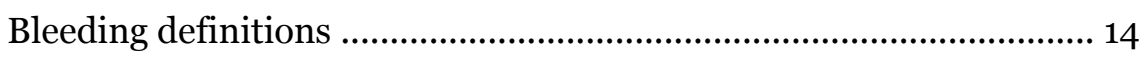

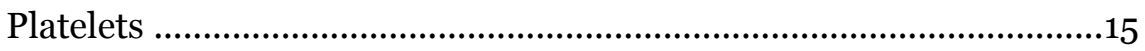

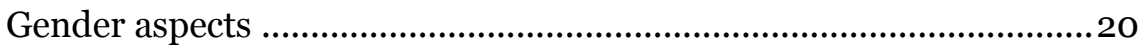

Health economy................................................................................... 21

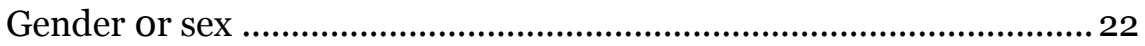

MATERIAL AND METHODS..................................................................... 23

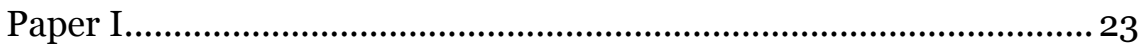

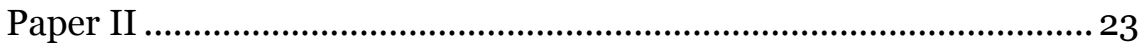

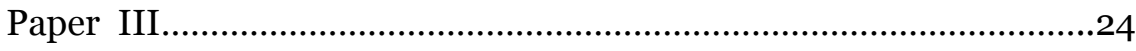

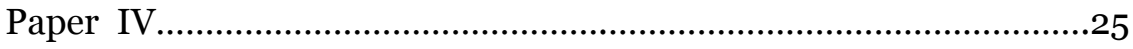

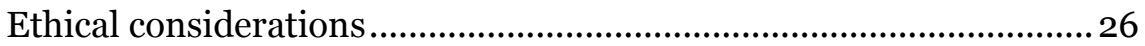

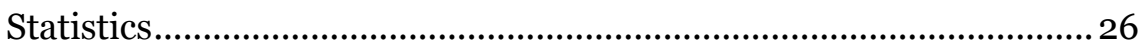




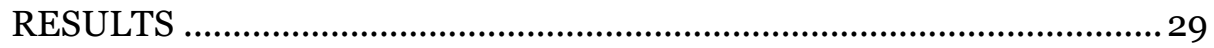

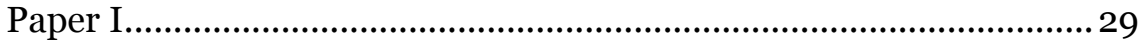

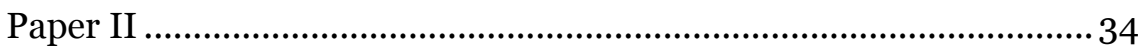

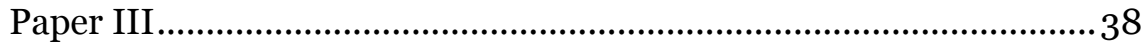

Paper IV …................................................................................... 44

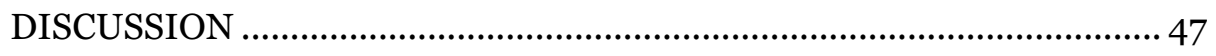

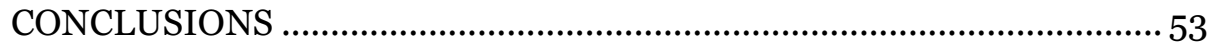

FOR THE FUTURE ............................................................................... 55

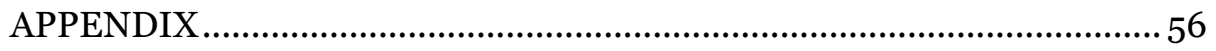

ACKNOWLEDGEMENTS …………………………………………….... 59

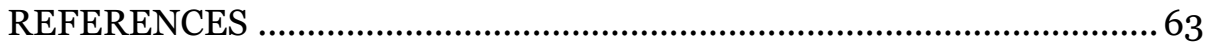




\section{ABSTRACT}

\section{BACKGROUND}

Bleeding complications increase mortality in patients with acute coronary syndrome (ACS). Potential gender difference in bleeding regarding prevalence, location, severity and prognostic impact is still controversial and not well investigated. In regard to this aspect the relevance of triple antithrombotic therapy (TAT) is questioned. There is an ongoing debate on the clinical implications of TAT and furthermore assumed that bleeding complications, except impact on outcome, also are associated with great influence on health economy.

The main focus of this thesis was to further investigate the incidence and impact of bleeding complications in patients treated for ACS, with special reference to gender disparities, TAT and health economics.

The thesis will highlight the importance of improved bleeding prevention strategies for both men and women.

\section{METHOD}

\section{Paper I, II and III}

Observational studies from the SWEDEHEART register.

In paper I we investigated patients hospitalised with myocardial infarction (MI) during 2006-2008. Outcomes were in-hospital bleedings, in-hospital mortality and one-year mortality in hospital survivors.

In paper II, all patients with MI, in the County of Östergötland, Sweden during 2010 were included and followed for one year. The patients' medical records were evaluated, in relation to short and long-term bleeding complications, bleeding location, withdrawal of platelet inhibiting drugs and nonfatal MI and death.

Paper III included all patients discharged with (TAT) in the County of Östergötland 2009-2015. Information about bleeds and ischemic complications during one-year follow-up were retrieved from the medical records. Estimation of the health care costs associated with bleeding episodes were added to the evaluation.

\section{Paper IV}

Patients with MI, scheduled for coronary angiography were recruited. All patients received clopidogrel and aspirin. A subgroup of patients received GP IIb/IIIa-inhibitor. Outcomes were platelet aggregation assessed at several time points, using a Multiplate impedance aggregometer, measurement of P-selectin in plasma, evaluation of high residual platelet reactivity (HRPR) and low residual platelet reactivity (LRPR) respectively and incidence of bleeding complications. A comparison between women and men was performed. 


\section{RESULTS}

\section{Paper I}

A total number of 50.399 patients were included, 36.6\% women. In-hospital bleedings were more common in women (1.9\% vs. $3.1 \%$, p<0.001) even after multivariable adjustment (OR 1.17, 95\%, CI 1.01-1.37). The increased risk for women was found in STEMI (OR 1.46, 95\% CI 1.10-1.94) and in those who underwent PCI (OR 1.80, 95\% CI 1.452.24).

In contrast the risk was lower in medically treated women (OR 0.79, 95\% CI 0.621.00). After adjustment, in-hospital bleeding was associated with higher risk of oneyear mortality in men (OR 1.35, 95\% CI 1.04-1.74), whereas this was not the case in women (OR 0.97, 95\% CI 0.72-1.31).

\section{Paper II}

In total 850 consecutive patients were included. The total incidence of bleeding events was $24.4 \%$ ( 81 women and 126 men, $\mathrm{p}=\mathrm{ns}$ ). The incidence of all in hospital bleeding events was $13.2 \%$, with no gender difference. Women had significantly more minor nonsurgery related bleeding events than men ( $5 \%$ vs $2.2 \%, \mathrm{p}=0.02$ ). During follow-up, $13.5 \%$ had a bleeding, with more non-surgery related bleeding events among women, $14.7 \% \mathrm{vs}$ 9.7\% ( $\mathrm{p}=0.03)$. The most common bleeding localisation was the gastrointestinal tract, more in women than men (12.1\% vs $7.6 \%, \mathrm{p}=0.03)$. Women also had more access site bleeding complications ( $4 \%$ vs $1.7 \%, \mathrm{p}=0.04$ ), while men had more surgery related bleeding complications $(6.4 \%$ vs $0.9 \%, \mathrm{p} \leq 0.001)$. Increased mortality was found only in men with non-surgery related bleeding events $(\mathrm{p}=0.008)$.

\section{Paper III}

Among 272 identified patients, 156 bleeds occurred post-discharge, of which $28.8 \%$ were of gastrointestinal origin. In total $54.4 \%$ had at least one bleed during or after the index event and $40.1 \%$ bled post-discharge of whom $28.7 \%$ experienced a TIMI major or minor bleeding. Women discontinued TAT prematurely more often than men (52.9 vs $36.1 \%, p=0.01$ ) and bled more (48.6 vs. $37.1 \%, p=0.09$ ). One-year mean health care costs were EUR 575 and EUR 5787 in non-bleeding and bleeding patients, respectively.

\section{Paper IV}

We recruited 125 patients (37 women and 88 men). We observed significantly more inhospital bleeding events in women as compared to men ( $18.9 \%$ vs $6.8 \%, \mathrm{p}=0.04)$. There were no differences in platelet aggregation using three different agonists, reflecting treatment of GPIIb/IIIa inhibitors, clopidogrel and aspirin, at four different time-points nor were there any differences in p-selectin in plasma 3 days after admission.

\section{CONCLUSION}

There is a remarkably high bleeding incidence among patients treated with DAPT and even more so if treated with TAT. Female gender is an independent risk factor of inhospital bleeding after myocardial infarction, this higher bleeding risk in women appeares to be restricted to invasively treated patients and STEMI patients. Even if women had higher short- and long-term mortality, there was no difference between the genders among those who bled. After multivariable adjustment the prognostic impact of bleeding complications was higher in men

Women seem to experience more minor/minimal bleeding complications than men, predominantly GI bleeding events and access site bleeding events, with no apparent impact on outcome.

In contrast men with non-surgery related bleeding complications had higher mortality. There is a lack of differences between the genders concerning platelet aggregation. Our results do not support gender disparities in platelet reactivity and excess dosing as a major explanation for increased bleeding risk in women.

Improved bleeding prevention strategies are warranted for both men and women. 


\title{
POPULÄRVETENSKAPLIG SAMMANFATTNING
}

\begin{abstract}
Bakgrund
Akut koronart syndrom (AKS) är ett samlingsnamn för allvarliga former av kärlkramp och hjärtinfarkt. Hjärtinfarkt kan delas upp i ST-höjningsinfarkt (STEMI) och icke ST-höjningsinfarkt (NSTEMI), beroende på utseende på EKG, där STEMI är av allvarligare karaktär med totalstopp i kranskärlet. Det orsakas av åderförfettning i hjärtats kranskärl, vilka ska tillse att hjärtat får syre och blodförsörjning till hjärtmuskeln. De vanligaste riskfaktorerna för åderförfettning i kranskärlen är hög ålder, manligt kön, rökning, höga blodfetter, diabetes, högt blodtryck och ärftlighet.

Behandlingen vid AKS är så kallad ballongvidgning av dessa förträngningar i kranskärlen och ofta lämnar man kvar ett metallnät, stent, för att hålla kärlet öppet. I samband med en hjärtinfarkt vill kroppen laga skadan i kärlet genom att bilda en propp av blodplättar, trombocyter, vilket i sin tur gör så att det blir än mer trångt i kranskärlet. För att undvika detta behandlar man med läkemedel som hämmar blodplättarnas förmåga att klumpa ihop sig och bilda proppar. Baksidan av att hämma blodproppsbildning i kroppen är att man också blöder lättare från t.ex. näsa och slemhinnor. Man får lättare blåmärken och kan också drabbas av allvarligare blödningar så som magblödning och hjärnblödning.

Syfte

Syftet med denna avhandling, som består av fyra delstudier, är att kartlägga förekomsten av blödningskomplikationer efter AKS, samt dessa blödningars lokalisation, allvarlighetsgrad och prognostiska betydelse. Ett övergripande syfte är också att kartlägga de eventuella skillnader mellan könen som finns inom dessa aspekter samt försöka belysa några förklaringsmodeller till dessa könsskillnader.
\end{abstract}

\section{Metod}

För att besvara dessa frågor har vi använt det nationella kvalitetsregistret, SWEDEHEART, som registrerar alla patienter med AKS i Sverige med avseende på bakgrundsfaktorer som längd, vikt, laboratorieprover, andra sjukdomar, medicinering samt data om det aktuella insjuknandet i AKS och den behandling varje individ erhåller. I studie 2 och 3 har vi även gjort noggranna genomgångar av patientjournaler och registrerat alla former av blödningskomplikationer som nämnts där. Studie 4 är en laboratoriestudie, där vi har tittat på blodplättarnas förmåga att klumpa ihop sig som svar på de hämmande läkemedel vi ger till patienter med hjärtinfarkt och om detta skiljer sig mellan kvinnor och män.

\section{Resultat}

I studie 1 inkluderade vi 50399 patienter från SWEDEHEART registret, 36,6\% kvinnor. Blödningskomplikationer under vårdtiden var vanligare hos kvinnor $(1,9 \%$ vs $3,1 \%)$. Den ökade risken för blödningar hos kvinnor sågs framförallt hos pat med STEMI (nästan 50\% ökad risk för blödning jämfört med män) och hos de som genomgick ballongvidgning (80\% ökad blödningsrisk jämfört med män). 
Blödningar under vårdtiden var associerade med död inom ett år hos män men inte hos kvinnor.

I studie 2 granskades de 850 patienter som under ett år insjuknade med hjärtinfarkt i Östergötland, vi följde dessa patienter i ett år med avseende på blödningshändelser som noterades i patient journalen. Total förekomst av blödningar var 24,4\%. Förekomst av blödningar under vårdtiden var $13,2 \%$ och $13,5 \%$ under uppföljningstiden. Kvinnor hade mer icke kirurgirelaterade blödningar samt fler mindre blödningskomplikationer jämfört med männen. Den vanligaste lokalisationen för blödning var i mag-tarmkanalen, där fler kvinnor än män hade en blödning. Kvinnor hade också fler blödningar relaterade till insticksställe vid kranskärlsröntgen och ballongvidgning jämfört med män. Män hade fler kirurgirelaterade blödningar jämfört med kvinnor. Ökad dödlighet under uppföljningen var associerat med icke kirurgirelaterade blödningar hos män enbart.

I studie 3 inkluderades 272 patienter som skrivits ut från sjukhus med trippelterapi (två blodplättshämmande läkemedel och ett läkemedel som hämmar blodets koagulationsförmåga) i Östergötland. Bland dessa patienter identifierade vi 156 blödningar efter utskrivning, 28,8\% från mag-tarmkanalen, 54,4\% hade minst en blödning under vårdtillfället eller efter utskrivning. Kvinnor tenderade att ha fler blödningar än män.

Dessa blödningar leder till ökade kostnader för samhället och i denna studie beräknades den vårdrelaterade kostnaden under ett år till i medeltal $5929 \mathrm{kr}$ för icke blödare jämfört med $59670 \mathrm{kr}$ för de patienter som hade en blödning. I den fjärde studien inkluderades 125 patienter med hjärtinfarkt, 37 kvinnor och 88 män. Här granskade vi på cellnivå blodplättarnas funktion och reaktion på tre olika läkemedel. Vi fann inga skillnader mellan kvinnor och män med avseende på trombocytaggregation efter tillsats av tre olika agonister som återspeglade behandling med tre olika trombocythämmare; GPIIb/IIIa hämmare, clopidogrel och aspirin, vid fyra olika tidpunkter. Det var inte heller någon skillnad i uppmätta värden av p-selektin i plasma. Vi fann även i denna studie att kvinnor hade fler blödningar än män

\section{Slutsats}

Det kanske viktigaste fyndet i denna avhandling är att det är mycket vanligt med blödningskomplikationer efter en hjärtinfarkt.

Kvinnor har fler blödningskomplikationer än män efter en hjärtinfarkt, de förefaller dock ha mindre allvarliga blödningar och det förefaller inte påverka deras prognos i samma utsträckning som hos de män som har en blödning.

I dessa fyra studier kunde vi inte verifiera förklaringsmodellen att kvinnor och mäns trombocytfunktion skiljer sig åt och att kvinnors ökade blödningskomplikationer delvis skulle kunna förklaras med överdosering av trombocythämmande läkemedel. För att kunna komma närmare svaret på frågan varför kvinnor blöder mer än män behöver fler kvinnor inkluderas i stora studier. Ytterligare forskning behövs för att kunna balansera risken och nyttan med vår behandling efter AKS. Blödningsförebyggande strategier behöver tas i bruk för både kvinnor och män. 


\section{LIST OF PAPERS}

I. Holm A, Sederholm Lawesson S, Swahn E, Alfredsson J Gender difference in prognostic impact of in-hospital bleeding after myocardial infarction - data from the SWEDEHEART registry

European Heart Journal: Acute Cardiovascular care 2016, Vol 5(6) 463-472

II. Holm A, Sederholm Lawesson S, Zolfagharian S, Swahn E, Ekstedt M, Alfredsson J

Bleeding complications after myocardial infarction in a real world population - An observational retrospective study with a sex perspective

Thrombosis Research 167 (2018) 156-163

III. Holm A, Henriksson M, Alfredsson J, Janzon M, Johansson T, Swahn E, Vial D, Sederholm Lawesson $S$

Long term risk and costs of bleeding in men and women treated with triple antithrombotic therapy - an observational study

Submitted

IV. Holm A, Swahn E, Sederholm Lawesson S, Gustafsson KM, Janzon M, Jonasson L, Lindahl TL, Alfredsson J

Sex differences in platelet reactivity in patients with dual antiplatelet therapy after myocardial infarction - results from assessing platelet activity in coronary heart disease (APACHE)

Manuscript 


\section{ABBREVIATIONS}

In alphabetical order

ACS

ADP

$\mathrm{AF}$

ASA

ASPI

AU

AUC

BARC

BMI

CABG

$\mathrm{CAD}$

CCU

CI

DAPT

DOAC

ESC

eGFR

GIB

GP

GPI

$\mathrm{H} 2$

$\mathrm{HR}$

HRPR

IC

IHD

IQR

LD

LMWH

LRPR

MI
Acute coronary syndrome

Adenosinediphosphate

Atrial fibrillation

Acetylsalicylic acid

Arachidonic acid

Arbitrary units

Area under the curve

Bleeding academic research consortium

Body mass index

Coronary artery bypass grafting

Coronary artery disease

Coronary care unit

Confidence interval

Dual antiplatelet therapy

Direct acting oral anticoagulation

European society of cardiology

estimated glomerular filtration rate

Gastrointestinal bleeding

Glycoprotein

Glycoprotein inhibitor

Histamin 2

Heart rate

High residual platelet reactivity

Intracranial

Ischemic heart disease

Interquartile range

Loading dose

Low molecular weight heparin

Low residual platelet reactivity

Myocardial infarction 
NSTEMI

OAC

OPR

OR

PCI

PPI

PRP

RCT

ROC

SAP

SD

SSRI

STEMI

TAT

TIA

TIMI

TRAP

TXA2

VTE

UAP

$\mathrm{UFH}$

Non ST-elevation myocardial infarction

Oral anticoagulation

Optimal platelet reactivity

Odds ratio

Percutaneous coronary intervention

Proton pump inhibitor

Platelet rich plasma

Randomised controlled trial

Receiver operator characteristic

Stable angina pectoris

Standard deviation

Selective serotonine reuptake inhibitor

ST-elevation myocardial infarction

Triple antithrombotic therapy

Transient ischemic attack

Thrombolysis in myocardial infarction

Thrombin receptor activating peptide

Tromboxane A2

Venous thromboembolism

Unstable angina pectoris

Unfractionated heparin 


\section{AIM}

To study incidence and gender differences in bleeding complications in patients with acute coronary syndrome

To evaluate how potiential gender-specific differences affect shortand long term outcome

To explore and describe how bleeding complications relate to health care costs

To study gender differences in platelet aggregation 


\section{INTRODUCTION}

The idea to write this thesis emerged from clinical experience and a hypothesis that bleeding complications in our patients are much more common than, we as cardiologists, are aware of. We also thought that this in part was a hidden problem that other specialities in the medical profession as surgeons, gastroenterologists, neurosurgeons and ear-nose and throat specialists discovered more often than we did. During the last decades bleeding complications have gained more and more attention, and thus also the potential differences between men and women according to bleeding issues. The aim of this thesis was to explore the bleeding events and the sex differences that may be present all the way from" cell to clinic". The first study was a large registry study, based on the national quality registry, SWEDEHEART, with quite rough variables measuring bleeding complications of greater dignity, followed by two studies assessing medical records at length and a much more thorough review of all bleeding complications receiving medical attention in the patient files and in the last study we went to the cell level and looked at the platelet function in the acute phase of ACS. 


\section{BACKGROUND}

\section{General background}

Ischemic heart disease (IHD) and myocardial infarction (MI) are common in both men and women over the age of fifty and is the leading cause of morbidity and mortality in Sweden(1) and worldwide.(2) Ischemic heart disease (IHD) comprises acute coronary syndrome (ACS) and stable angina pectoris (SAP). IHD is mainly caused by atherosclerosis, a generalised and progressive process, caused by inflammation of the vessel wall and endothelial dysfunction. $(3,4)$ It can be clinically silent for decades and then suddenly manifested as SAP or ACS. Upon progression of the atherosclerosis, focal lesions, atherosclerotic plaques, are formed. This causes luminal narrowing of the coronary arteries resulting in chronic ischemia. When these plaques rupture it leads to exposure of highly thrombogenic components, which in turn activates platelets and parts of the coagulation system (5) and eventually leads to the formation of a platelet rich thrombus. $(5,6)$ (Figure 1). When thrombus formation occurs in a coronary artery it may lead to ACS which this thesis will mainly focus upon.

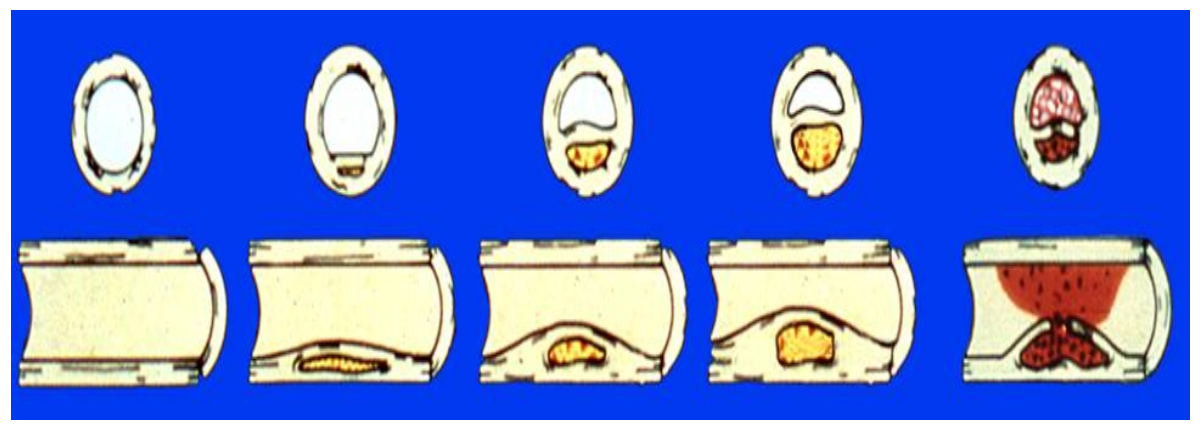

Figure 1. Plaque formation and rupture. Reprinted with permission.

\section{Acute coronary syndrome definition and antiplatelet treatment}

ACS is the collection term for ST-elevation myocardial infarction (STEMI), non ST-elevation myocardial infarction (NSTEMI) and unstable angina pectoris (UAP). The clinical manifestation may differ but the cause of the condition is the same, with insufficient blood supply causing cardiac myocyte damage.

Platelet acticvation and clot formation play a very important role in the pathogenesis of ACS. Dual antiplatelet therapy (DAPT) is a cornerstone in the treatment of patients with ACS, in the acute phase, in connection with percutaneous coronary 
intervention (PCI) as well as in secondary prevention during first year of followup. DAPT consists of aspirin and a P2Y12-inhibitor, $(7,8)$ the more recently developed drugs ticagrelor or prasugrel have shown to lower the risk of ischemic events but with a higher bleeding risk and are recommended in clinical guidelines.(9-12) However, clopidogrel is still the most commonly used P2Y12-inhibitor worldwide, partly because it's lower price, but also because it's association with lower bleeding risk compared to the newer drugs.

Approximately $10 \%$ of patients with ACS require long-term oral anticoagulants (OAC) because of prosthetic heart valves, thromboembolism or atrial fibrillation (AF).(13) OAC has been found superior to DAPT in order to prevent from thromboembolic events,(14) and thus these patients are often discharged with both DAPT and OAC, so called triple antithrombotic therapy (TAT).(15)

\section{Bleeding}

Bleeding is the most common non-ischemic complication in patients with ACS, and has gained much attention due to its association with worse outcome.(16-18) Data from the GRACE registry have shown a bleeding incidence of $2.7 \%$ in unstable angina, $4.7 \%$ in NSTEMI and $4.8 \%$ in STEMI. Age, female gender, renal insufficiency, previous bleeds and the use of glycoprotein (GP) IIb/IIIa inhibitors were independently associated with higher risk of bleeding complications. $(19,20)$ Previous studies have shown that patients with TAT have up to four times higher risk of major bleeds than those with OAC only.(21) Despite the strong association between bleeding and adverse outcome in patients with ACS the causal relationship between bleeds and adverse outcome remains uncertain.(22) Bleeds can be a surrogate marker for other conditions and comorbidities giving higher risk for adverse events or it can be the direct cause of increased morbidity and mortality via different mechanisms. Hypothetically bleeding itself can lead to circulatory failure, fatal organ damage and anemia as one possible explanation, another being that bleeding is causing withdrawal of antithrombotic drugs after ACS and thus can cause new ischemic events.(23-25) Blood transfusion has also been under debate and has shown contradictory results whether it is harmful or not.(26-28)

\section{Bleeding definitions}

Several bleeding definitions have been used in clinical trials and registries concerning ACS and PCI populations, and there is a lack of uniformity among these definitions.(29-31) Current bleeding definitions include laboratory parameters, clinical signs, degree of bleeding and need of transfusion or surgery.

Each definition incorporates a different combination of these data elements and then ranks these combinations into severity categories, which vary widely between definitions. This makes it difficult to compare results and degree of bleeding complication between different studies and different populations. Thus it is important 
to be aware of which definition is used wen you read an article on this topic. In this thesis we use the TIMI and BARC definitions.

The Thrombolysis in Myocardial Infarction (TIMI) bleeding criteria have been used for nearly 30 years, and have been reported in most cardiovascular trials. They were developed to define and classify major and minor hemorrhagic events in patients with STEMI treated with a fibrinolytic drug. The original TIMI definition relies predominantly on laboratory data based on decreases in hemoglobin or hematocrit values after adjustment for the effect of blood transfusion. (32) Over time, the definitions have evolved to represent a broader range of bleeding categories and events while specifically defining each individual category.(33-35)

Potential limitations of the TIMI definition include that it was developed in the fibrinolytic era, and thus typically characterised severe acute events, and difficulties with perception of the nomenclature, many would consider TIMI minor bleeding to hold greater clinical significance than that connoted by the term minor.(36)

The Bleeding Academic Research Consortium for Bleeding (BARC) bleeding criteria were developed to try to find a universal definition. The criteria is a consensus from several expert groups with experience in considering outcomes in cardiovascular clinical trials and registries and is based on a review of prior definitions. (36)

For details on TIMI and BARC bleeding definitions see appendix.

\section{Platelets}

\section{Platelet function and activation}

Platelets are nucleus free components of the blood with a diameter of $2-4 \mu \mathrm{m}$. They are derived from megakaryocytes in the bone marrow and circulate in a discoid form when not activated. They have a life span of 8-10 days and are then cleared from the blood by liver and spleen.(37)

A healthy person has around $150-400 \times 10^{9}$ platelets/L. The main role for platelets is to preserve hemostasis and prevent bleeding. However platelets are also involved in many other processes such as inflammation, infection, angiogenesis and cancer. $(38,39)$ Apart from this, it is clear that, platelets play a key role in atherothrombosis and ACS.

Platelets play a critical role in hemostasis and activate in response to a vessel wall injury, in ACS it usually is the plaque rupture that initiates the widespread platelet activation. Platelet receptors help slowing platelets down via activators as von Willebrand factor and thus facilitate their contact with exposed collagen at the site of the injury and this is followed by more platelets that are incorporated into the growing thrombus.(40) Platelet activation is a multistep process including gatheringadhesion-activation (shape change, turn on receptors, secretion) and aggregation. This leads to formation of a platelet plug (primary hemostasis), (41) and this, in turn, activates the coagulation cascade linking the process to the secondary hemostasis.(42) $(37,43)$

When platelets activate they change shape from discoid to irregular with protruding pseudopodia, increasing the platelet surface and facilitating the aggregation 
process with coagulation factors being accumulated and activated on the surface. This leads to thrombin formation and fibrin formation. The activated platelets also release platelet agonists such as adenosindiphosfate (ADP) and thromboxane A2 (TXA2)(6)

Activated platelets also release the adhesion molecule p-selectin, involved in inflammatory and hemostatic processes, which is stored in $\alpha$-granules and degranulated on the membrane. P-selectin is present as membrane bound and soluble(38) and soluble p-selectin can be used as a surrogate marker of platelet activation. Prevention of thrombosis while maintaining hemostasis is a major challenge and goal of medical research in many fields and so also in ACS.

\section{Platelet receptors}

Platelet receptors are at the forefront of recent research and major advances have been made in understanding their molecular functions and their signaling pathways. A wide variety of mobile transmembrane receptors cover the platelet membrane, including the integrins of wich the GPIIb/IIIa is one important receptor, involved in platelet aggregation. Other types of platelet receptors are the leucine rich repeated receptors, tetraspanins, selectins (p-selectin), purinergic receptors (P2Y12 receptor) and prostaglandin receptors (Thromboxane receptor). Many of these receptors are shared by other cell types, but some are only expressed on platelets.(37) (Figure 2)

\section{Platelet inhibitors}

\section{Acetysalicylic acid}

ASA acts mainly by irreversible (acts throughout the whole lifetime of a platelet) inactivation of cyclooxygenase-1(COX-1). This causes inhibition of thromboxane A2 (TXA-2) mediated inhibition of platelet aggregation. (44)

Comparison of dosing has shown similar effect independent of increased dosing but at the expense of more bleeding complications.(45)

Treatment with ASA is recommended in European Society of cardiology (ESC) guidelines in treatment of stable CAD in a maintenance dose of 75-100 mg daily, as well as in ACS with a LD of 150-300 mg and thereafter 75-100 mg once daily.(11, 46, 47)

Already over thirty years ago randomised trials showed increased survival and reduction of vascular events with ASA (48-50) which has been confirmed in several trials later on. $(51,52)$

Some studies have shown similar effect of ASA in men and women (51), while other studies indicate difference in response and that men have a greater inhibition of platelet aggregation in vitro (53) and that female gender is associated with higher platelet reactivity in ASA treated patients with CAD.(54) 


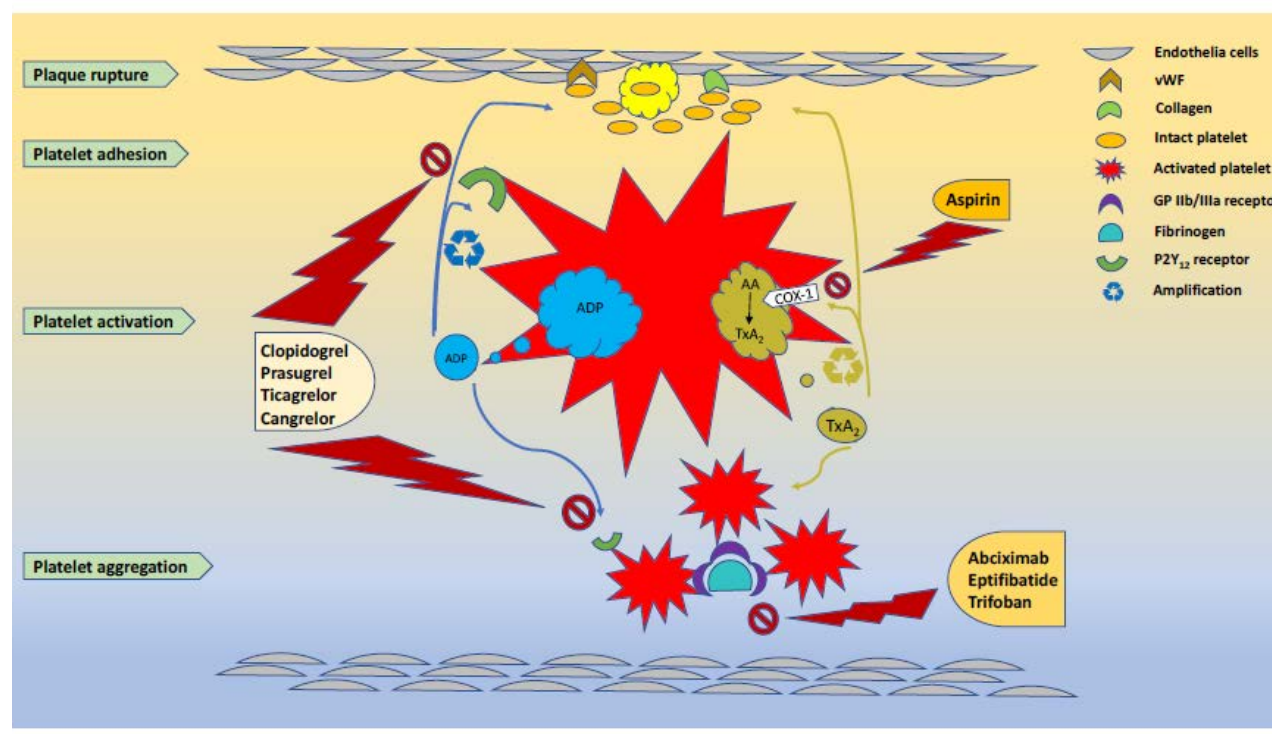

Figure 2. Overview of platelet activation and the effects of antiplatelet treatment. ADP, adenosine diphosphate; AA, arachidonic acid; $\mathrm{TxA}_{2}$, thromboxane $\mathrm{A}_{2}$; COX, cyclooxygenase; vWF, von Willebrand factor; GP, glycoprotein. Reprinted with permission from the author. (55)

\section{Adenosine diphosphate (ADP)-receptor antagonists Clopidogrel}

Clopidogrel is a prodrug and is metabolised by the CYP450 enzyme system in the liver to an active metabolite, which is an effective platelet aggregation inhibitor. Clopidogrel inhibits binding of ADP to its' P2Y12-receptor on the platelet and inhibits soforth the ADP mediated activation of GPIIb/IIa complex and thereby inhibits platelet aggregation.(44) Clopidogrel inhibits platelets to about $40-60 \%$ (56) (57) and the effect of inhibition varies between individuals. The binding is irreversible and affects the platelet for the rest of its'lifetime. Recovery of platelet function is that of normal platelet turnover. The CYP450-enzyme system can be inhibited by other drugs and some patients will have a polymorphism, most often which reduces the effect of clopidogrel but there are also known polymorphisms that increase the effect.(58) In summary not all patients will recieve the same platelet inhibition. There is a large interindividual variation in response to clopidogrel treatment and previous studies have indicated higher risk of thrombotic events in patients with high residual platelet reactivity (HRPR), $(59,60)(61)$ on the contrary low residual platelet reactivity (LRPR) have been associated with a higher risk for bleeding complications.(62) Most commonly, the receiver-operator characteristic (ROC) curve analysis has been used to define the optimal cut point definition of high on-treatment platelet reactivity associated with ischemic risk. This method allows us to determine the cutoff value of platelet reactivity that would be associated with the lowest false negative and false positive rates and thus provides the 
greatest sum of sensitivity and specificity.(63) Based on previous studies, HRPR on clopidogrel treatment is often defined as $>468 \mathrm{AUC} * \min$ and LRPR as $<188$ AUC*min. $(64,65)$

Many clinical studies have revealed that the pharmacodynamics of clopidogrel do not differ between women and men (66-68), whereas other studies report decreased risk of HRPR among men as compared to women. (69) (70)

Clopidogrel in addition to ASA has proved effective in NSTEMI (71) as well as STEMI (72) populations, reducing a combined outcome of death, MI and stroke. A meta-analysis of randomised clinical trials on clopidogrel treatment focusing on the gender aspect showed significant reduction in the combined outcome (cardiovascular death, MI and stroke) with no significant gender difference in treatment effect. In women the overall effect was driven by a reduction in MI, while men had separately significant reduction in cardiovascular death, MI and stroke.(73) The recommended administration of clopidogrel is a LD of 300-600 mg, followed by $75 \mathrm{mg}$ once daily. $(11,47)$

\section{Prasugrel}

Prasugrel inhibits ADP-induced platelet aggregation by binding irreversibly to the P2Y12-receptor on platelets. Prasugrel has a more favourable metabolic conversion to active metabolite, compared to clopidogrel. Prasugrel has a low variability between individuals $(9 \%)$ and within the same individual $(12 \%)$ and it does not seem to be as affected of CYP genetic variants. $(58,74)$ Prasugrel inhibits platelet aggregation between $74-69 \%$. (75)

When prasugrel was tested against clopidogrel in ACS patients, prasugrel was proven more effective in reducing ischemic events but had an increased incidence of severe bleeding complications. $(9,76)$

Prasugrel is recommended in a LD of $60 \mathrm{mg}$, followed by $10 \mathrm{mg}$ once daily.(11, 47)

\section{Ticagrelor}

Ticagrelor is an oral direct acting, selective, P2Y12-receptor antagonist that inhibits ADP-dependent platelet activation and aggregation. Ticagrelor does not inhibit binding to the ADP-receptor but the ADP-induced signal transduction.Ticagrelor is a fast acting and effective platelet inhibitor, and $90 \%$ of the patients had a platelet inhibition $>70 \% 2$ hours after administration.(75)

A comparison between clopidogrel and ticagrelor was done in the PLATO study, showing a significant reduction in combined ischemic outcome (cardiovascular death, MI and stroke) in favour of ticagrelor, with similar results in terms of major bleedings and similar reduction in primary outcome between men and women.(77) Ticagrelor is recommended in a LD of $180 \mathrm{mg}$, followed by $90 \mathrm{mg}$ once daily. (11, 47) 


\section{Glycoprotein (GP) IIb/IIIa inhibitors}

Abciximab is the Fab-fragment of a monoclonal antibody. It is directed to the GPIIb/IIIa receptor on the surface of platelets. Abciximab inhibits platelet aggregation by blocking the binding of fibrinogen, von Willebrand factor and other adhesive molecules to the GPIIb/IIIa receptor on activated platelets.(75) Eptifibatide is a small protein, peptide, and tirofiban mimics a peptide, that contains the part of fibrinogen that binds to the GP IIb/IIIa receptor.(78)

A meta-analysis of randomised trials on GPIIb/IIIa antagonists in patients with UAP and NSTEMI, showed a modest benefit in the combined outcome death/MI within 30 days. The most benefits were seen in patients with risk features such as elevated troponins or ST segment depression. A subgroup analysis showed significant benefit in the male cohort while harm was indicated in women.

Patients undergoing PCI or coronary artery bypass grafting (CABG) have been shown to have greater benefit compared to those not revascularised. $(79,80)$

\section{Measurement of platelet function}

Platelet function testing can be difficult, time consuming and have a wide variability according to pre-analytical variables and diverse methods in different laboratories. It is used in studies as well as in clinical practice to measure platelet response to antiplatelet treatment, detection of bleeding disorders and to evaluate platelet function pre- per- and postoperatively.

\section{Light Transmission Aggregometry}

In 1960, Gustav Born was appointed head of the Department of Pharmacology at the Royal College of Surgeons in London. During the next 13 years his research center made great advances in platelet biology. The advances were made possible by the evolution of the platelet aggregometer, conceived and developed by Born and his team, it became a reliable scientific instrument, with which they revolutionised the study of platelet function. For the first time, the actions of agonists and antagonists could be quantified pharmacologically, and the biochemistry of aggregation analysed.(81)

Platelet aggregation testing measures the ability of various agonists to platelets to induce in vitro activation and platelet-to-platelet activation. Classically Born aggregometry uses platelet rich plasma (PRP) but whole blood aggregometry can also be used. In the Born aggregometer, PRP is stirred in a cuvette at $37^{\circ} \mathrm{C}$ and the cuvette sits between a light course and a photocell. When an agonist is added the platelets aggregate and absorb less light and the transmission increases and this is detected by the photocell.

Citrate remains the most widely used anticoagulant during platelet function testing, although it affects intracellular calcium ion concentrations, which may influence platelet function. Alternatively, D-phenylalanyl-L-prolyl-L-arginine chloromethyl ketone or hirudin may be used to reduce changes in calcium ion concentrations. Many other procedures may be involved in the performance of light transmittance aggregometry which are not standardised between diverse institutions, this entails that light transmittance aggregometry may not be the ideal test to monitor the effects of antiplatelet therapy outside of clinical trials.(82) 


\section{Multiplate impedance aggregometer}

This method is based on whole blood impedance aggregation, with two pairs of electrodes per test channel, so called multiple electrode aggregometry. This increases the precision in measurements and makes the procedure faster. The use of hirudin as an anticoagulant is preferable to the use of citrate, see above. Hirudin blood is then mixed with different agonists and the platelets aggregate and ackumulate on the electrodes which changes the impedance between the electrodes. The change in impedance is registered and is typically presented as a function of time, area under the curve (AUC), and it is proportional to the degree of platelet aggregation.

Multiplate is an easy, reproducible and sensitive method for measuring spontaneous and stimulated platelet aggregation, and evaluating antiplatelet drugs in diluted whole blood.(83) This is the method used in paper IV in this thesis.

\section{Gender aspects}

After adjustment for age, men still have a higher mortality than women in MI populations.(84) Women with MI, especially with STEMI, have higher in-hospital mortality than men.(20) Their higher burden of risk factors can, at least partly explain this phenomenon.(85) Analysis adjusted for risk factors and comorbidities decrease these differences in mortality. The varying results can, among other things, depend on which age group is studied. Young women have been identified as a special risk group. $(85,86)$

Several previous studies have reported an increased risk of bleeding in women with ACS, compared to men.(87-89) The reasons for the observed differences are incompletely understood, but clustering of other conditions associated with increased risk of bleeding, such as high age, low weight and impaired renal function has been suggested. Influence of gender on platelet biology has also been a theory for over 40 years. (90)

For example, another possible contributory explanation can be differences in platelet function. It is previously known that women have higher values of platelet count, (91) but higher platelet count has been coupled to higher platelet reactivity and rather higher thrombotic risk.(92) Differences in dosage of antithrombotic drugs have also been put forward as a possible explanation. In previous studies it was suggested that women have a higher number of platelet surface receptors, for example GP IIb/IIIa receptors(93), which could be the reason why women seem to bleed more when given GPIIb/IIIa inhibiting drugs.

Women bleed more than men when treated with DAPT, $(88,89,94)$ even if the reduced risk for a new clot is equal. $(9,10,95)$ Older women have an increased 
tendency to bleed, as have been shown in studies considering antiplatelet therapy and invasive procedures.(96)

Caution is warranted when interpreting data on gender differences in platelet function because there is a large heterogenicity and frequent fluctuations during lifetime with pre-/post-menopausal state, oral contraceptives, pregnancy, hormone replacement therapy and so forth, all of these factors with potential impact on platelet reactivity.

There are important differences in baseline characteristics and treatment patterns between women and men with myocardial infarction (MI), but it is not well known how this relates to the observed differences in bleeding. Neither is it known whether, in addition to the observed gender difference in bleeding prevalence, there is a difference in prognostic impact of bleeding complications.

At least 20 percent of women with normal or near normal coronary arteries suffer from ischemia, implicating endothelial dysfunction. One explanation to this could be that women do not develop atherosclerotic stenosis, but instead have an increased platelet activity, an increased tendency for thrombosis or a decreased tendency to fibrinolysis, separately or in different combinations. Mechanisms like that may lead to vessel constriction and to ischemia. $(97,98)$

Women have been shown to have higher blood levels of markers for haemostasis and thrombosis, like tissue-Plasminogen Activator and its inhibitor PlasminogenActivator Inhibitor, antithrombin III, protein $\mathrm{C}$ and tissue factor. So far no study has been able to show that these differences can explain a higher tendency for thrombosis. $(99,100)$

Since the mean percentage of women included in studies is about $30 \%$ and this has not changed over the last 20 years, consistent with the finding in the current thesis, there is an urgent need to include more women in studies in order to properly be able to assess questions about gender differences and soforth give evidence-based recommendations.

\section{Health economy}

Recurrent cardiovascular events as well as bleeds is a burden not only for the patient but also for the health care sector and for the society at large. Clinical trials have reported an average healthcare cost of approximately EUR 13000 at 12months follow-up after MI in a European setting.(101) An understanding of health care costs associated with bleeding complications in general and in association with TAT specifically is lacking. 


\section{Gender or sex}

This topic deserves a short explanation and reasoning, since we use diverse terms in the papers to express differences between women and men.

Traditionally the distinction between sex and gender means sex as a biological term, referring to the reproductive system, internal and external genitalia and genetics with different levels of hormones and settings of chromosomes. Gender on the other hand is traditionally more difficult to define referring to social roles based on the sex of a person, gender roles, or personal identification of the gender identity.(102) Gender is based on norms, roles and relationships and varies between different societies and cultures and it can also be changed.

Later research implies anyhow, that also sex can be changed and that there are natural variations in levels of hormones and chromosomes that make this term more difficult to define as well.

One can claim that our research is mainly about sex since we do not investigate anything about gender roles or gender identity in our studies. But on the other hand it is probably difficult to make decisions about medications, interventions and more, without, unconsciously, taking into account the preconceived roles and identity that we connect with the female and male gender respectively.

In ordinary speech, sex and gender are often used interchangeably, and different journals prefer one or the other when writing about this issue which is the reason for the different terms used in this thesis. 


\section{MATERIAL AND METHODS}

\section{Paper I}

We used data from the Swedish Web-system for Enhancement and Development of Evidence based care in Heart disease Evaluated According to Recommended Therapies (SWEDEHEART) (http:/www.ucr.uu.se/swedeheart) register. We included 50.399 patients (36.6\% women) diagnosed with MI during the years 2006-2008, with at least one-year follow-up. The details of the register have been previously published.(103) SWEDEHEART is a national register where all coronary care units (CCUs) in Sweden register their patients including variables such as baseline characteristics, symptoms on arrival, ECG findings, angiographic findings, medication at discharge, comorbidities, etc. The register also includes SCAAR (Swedish Coronary Angiography and Angioplasty register), SEPHIA (the register for secondary prevention and follow-up after myocardial infarctions) and the Swedish Heart Surgery Registry. To obtain detailed information on comorbidities the database was linked to the National Patient Register, which collects all discharge diagnoses for patients admitted to hospitals in Sweden since 1987.

\section{Outcomes}

Bleeding complications during hospital stay were compared between women and men. Bleeding was defined according to a modified TIMI criteria (32) as fatal, intracranial, requiring transfusion or surgical intervention, or as a decrease in haemoglobin $\geqslant 30 \mathrm{~g} / 1$ ( $\geqslant 40 \mathrm{~g} / 1$ if occult). CABG-associated bleeding was not included. Mortality data were available for all patients and were obtained from the SWEDEHEART (in-hospital mortality) and the National Cause of Death Register (long-term mortality) respectively.

\section{Paper II}

We used data from the SWEDEHEART registry (see paper I) to identify all patients with MI in our region, from 2010-01-01 to 2010-12-31.

To capture all bleeding complications we undertook a detailed search of each individual patients' medical records. A template was used to ensure a standardised review of bleeding events during hospitalisation and one year follow-up. Thereafter, data from the templates were merged with the SWEDEHEART database. 


\section{Outcomes}

Short (during hospital stay) and long-term (from discharge to one year follow-up) bleeding complications were registered, and characterised according to the TIMI definition.(32) Surgery-related and non-surgery related bleeding events are presented separately. In addition, non-surgery related bleeding localisations, defined as gastrointestinal, intracranial, urogenital, access site, pseudoaneurysm or other, are presented. We also studied if patients had their platelet inhibiting drugs withdrawn after a bleeding episode.

Finally we assessed clinical outcome (nonfatal MI or death) and the association with bleeding. Included MI is MI occurring after a bleeding event. MI diagnosis was made according to current guidelines.(104)

\section{Paper III}

We identified patients discharged with TAT from any of the three cardiology wards in the County of Östergötland, Sweden, between 1 January 2009 and 31 December 2015. This time period was chosen as the electronic data record was started in 2008 in the County of Östergötland, and we wanted to have access to data for at least one year before and one year after the index event. Patients from other counties were excluded due to lack of access to their patient files during follow up. No other inclusion or exclusion criteria were applied. We used data from the SWEDEHEART registry (see paper I) to identify the patients for inclusion. In the County of Östergötland approximately 800 patients with ACS are treated annually, and are registered in SWEDEHEART. For patients with more than one hospitalisation registered during the inclusion time window, only data from the first one was recorded. A predefined template was developed to retrieve relevant information about each patient from their medical records. Over 200 variables were recorded including comorbidities, bleeding and ischemic events, medication and laboratory data. Each bleeding and ischemic complication was reported. From the registry 274 unique patients were identified, of whom two were excluded in the medical record retrieving data process, as they were never prescribed TAT. Our final study population consisted of 272 patients.

\section{Outcomes}

The primary outcome measure was the occurrence of any bleeding complication receiving medical attention within one year after discharge from the index event. Secondary outcome measures were bleeding complications in-hospital, premature discontinuation of TAT, total rate of bleeding events, one-year rate of ischemic events, as well as one-year mortality. Two standard bleeding classifications were used to measure the severity of each bleeding event, TIMI (Thrombolysis In Myocardial Infarction), (32) and BARC (Bleeding Academic research Consortium).(36) A secondary explorative outcome was the per patient mean health care costs, from discharge to the end of study follow-up. Resource use data retrieved in the study included hospitalisations, outpatient care visits, procedures and blood products. Unit costs used to value resource use and calculate health care 
costs were derived from administrative data bases at Linkoping university hospital.(105)

\section{Paper IV}

Between Jan 2009 and Aug 2011125 patients with STEMI or NSTEMI planned for coronary angiography were included at the department of cardiology in Linköping. Exclusion criteria were participation in an intervention study, treatment with warfarin before admission, life expectancy shorter than six months or unwillingness to participate. All patients received a loading dose (LD) of 600mg of clopidogrel, followed by $75 \mathrm{mg}$ once daily. If a patient was not on aspirin treatment on admission, a LD of 300mg aspirin was given, followed by $75 \mathrm{mg}$ once daily. Coronary interventions were made according to current guidelines and choices of stents according to the treating physicians' discretion.

Venous blood samples were collected into blood collection tubes containing hirudin as an anticoagulant at the following time points:

6-8 hours after LD

3 days after LD

7-9 days after LD

6 months after LD

Platelet activity was measured using a Multiplate impedance aggregometer.(83) Aggregation was initiated with

-adenosinediphosphate (ADP) to measure the effect of ADP receptor antagonists e.g. clopidogrel

-arachidonic acid (ASPI) to measure the effect of cyclooxygenaseinhibitors like aspirin

-thrombin receptor activating peptide (TRAP) to assess the effect of very potent aggregation inhibitors as GPIIb/IIIa-inhibitors.

Impedance is measured between two electrodes in the test cuvettes. When platelets activate, they adhere and aggregate on the electrodes, increasing the impedance. The impedance as a function of time, area under the curve (expressed as Arbitrary Units $\left.(\mathrm{AU})^{*} \mathrm{~min}\right)$ is proportional to the degree of platelet aggregation. Soluble p-selectin was measured as a surrogate marker of platelet activation.

\section{Outcomes}

Incidence of bleeding events, defined according to the TIMI definition.(32) We measured platelet aggregation at different time points and calculated High residual platelet reactivity (HRPR) and low residual platelet reactivity (LRPR) on clopidogrel treatment. ADP stimulated aggregation $>468$ AUC*min was considered HRPR and $<188$ AUC*min as LRPR. $(64,65)$

All analyses were made from a sex perspective with comparisons between women and men. 


\section{Ethical considerations}

All studies was performed according to good clinical trial practice and complies with the Declaration of Helsinki.

Paper I was an observational retrospective register study. Using the SWEDEHEART registry. In accordance with the ethical regulations for Swedish registries all patients were informed about their participation in the registry and had the right to refuse participation. The registry and the merging of registries were approved by the Swedish National Board of Health and Welfare, and the local ethical review board at Stockholm University.

Paper II was an observational retrospective study with merging of data from the SWEDEHEART registry (see above according ethical regulations for registers) with information from patients medical records. We obtained approval from the local ethical review board in Linköping.

Paper III was an observational study with thorough examination of medical records. The patients were identified for inclusion in the study via the SWEDEHEART registry (see above according ethical regulations for registers).Permission for the study was obtained from the local ethical review board in Linköping. Paper $I V$ was a prospective laboratory study with blood sampling from patients with myocardial infarction in Linköping. All patients gave written informed consent.

All patient data were anonymised to protect integrity.

\section{Statistics}

The statistical analysis were performed with IBM SPSS Statistics version 21.0, 23.0 and 24.0 and the health economic analyses in paper III were performed with Stata Statistical Software version 14.

All continuous variables in paper I, II and III were normally distributed and are presented by their means and standard deviations (SD). In paper IV some variabels were not normally distributed and are hence presented as medians with interquartile ranges (IQR). Categorical variables are presented as counts and percentages. The students' T-test was used when comparing continuous variables with a normal distribution and with Mann-Whitney $U$ test when appropriate. The chi-square test was used when comparing the distribution of categorical variables.

A p-value of $<0.05$ was considered significant.

Time to events was estimated using Kaplan-Meier curves. Crude and multivariable adjusted hazard ratios (HR) with 95\% confidence intervals (CI) were calculated (in paper I Odds ratio (OR) was calculated from logistic regressions) from Cox regression analyses in order to compare women and men with regard to bleeding complications and mortality. In the adjusted models were variables known to be independently associated with bleeding in ACS patients included.

In paper III health care costs are summarised in terms of descriptive statistics and reported as per patient means and standard errors, costs by sex were also reported. 
In paper IV there was a power calculation made for the main analysis, not presented in this thesis. This analysis was based on two previous studies measuring platelet aggregation in patients with NSTEMI and STEMI.(106) Based on these studies it was presupposed that $75 \%$ of clinical events after ACS would occur in the quartile with highest platelet activity. With $80 \%$ power assuming an incidence of $10 \%$ of the primary outcome we would need 60 patients to detect statistically significant difference $(\mathrm{p}$-value $=0.05)$ between the quartile with the highest platelet aggregation and the rest of the study population. It was presumed a low number of events though and soforth chose a power of $95 \%$ and accordingly to include 120 patients. The analysis with sex specific alignment was a prespecified subgroup analysis. 


\section{RESULTS}

\section{Paper I}

\section{Baseline characteristics}

In this large register study, we included 50399 consecutive patients with MI (36.6\% women). We found men with bleeding events to be older, with lower body weight, lower blood pressure and haemoglobin values, higher heart rate and more comorbidities compared to men without a bleeding event.

In women, on the contrary, we did not find any differences in age, weight or comorbidities when comparing those with a bleeding event with those without a bleeding event. We did find lower blood pressure, lower haemoglobin values and lower estimated glomerular filtration rate (eGFR) among the women with bleeding complications as well as compared to those who did not have a bleeding complication.

When we did a comparison between men and women with a bleeding complication we found men to be younger, heavier, with better kidney function and more often previous MI, CABG, other surgery, stroke and cancer.

\section{Interventions and medications at discharge}

Men who had a bleed were less often treated with PCI compared to those who did not have a bleeding complication, while in women the opposite were found, women who had a bleeding event had more PCI performed.

Complications as cardiac arrest, cardiogenic schock, atrial fibrillation and re-infarction were more common in those who had a bleeding event in both men and women.

In both genders, they who had a bleeding event were less often prescribed platelet inhibitors compared to them without a bleed, especially DAPT. The group without a bleeding event were more often prescribed beta-blockers in both genders. Men without a bleed were also more often prescribed warfarin, statins and ACE-inhibitors compared to those without a bleeding complication.

When comparing men and women with a bleeding event, we found that during hospital stay men had more CABG surgery whereas women had more coronary angiography and PCI. Women were prescribed more aspirin, adenosine diphosphate (ADP) receptor inhibitors and DAPT at discharge.

\section{Bleeding events and prognostic impact}

The rate of bleeding during hospital stay was higher in women compared with men. The rate of bleeding during hospital stay was higher in women compared with men, $3.1 \%$ vs. $1.9 \%$, (OR $1.71,95 \%$ CI $1.53-1.92), p<0.001$. After multivariable adjustment women still had 17\% higher bleeding risk (OR 1.17, 95\% CI 1.01-1.37). There was a significant interaction between bleeding, gender and type of MI, invasive treatment, renal function and age (all interaction $\mathrm{p}$-values $<0.001$ ).

(Table 1) 


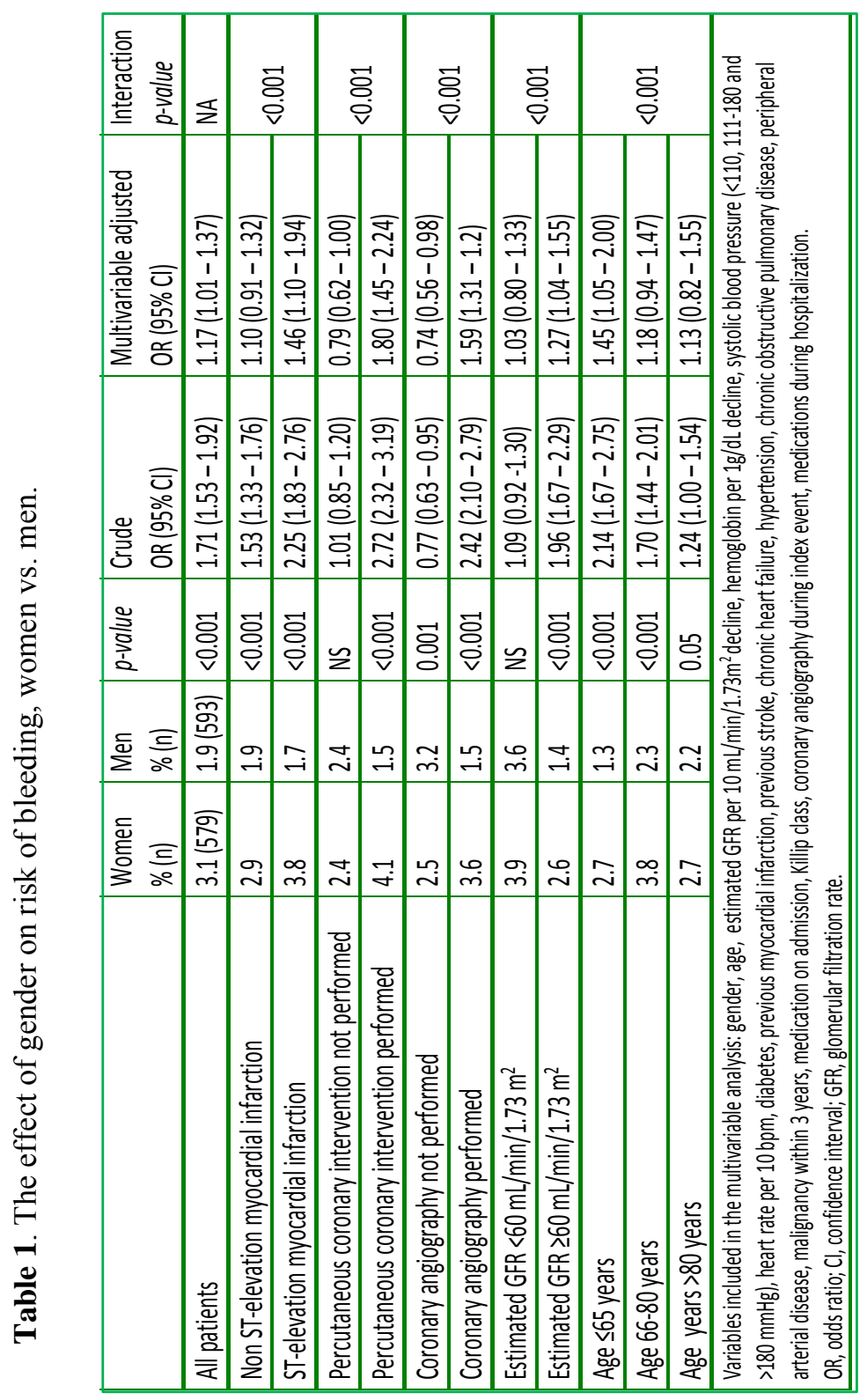




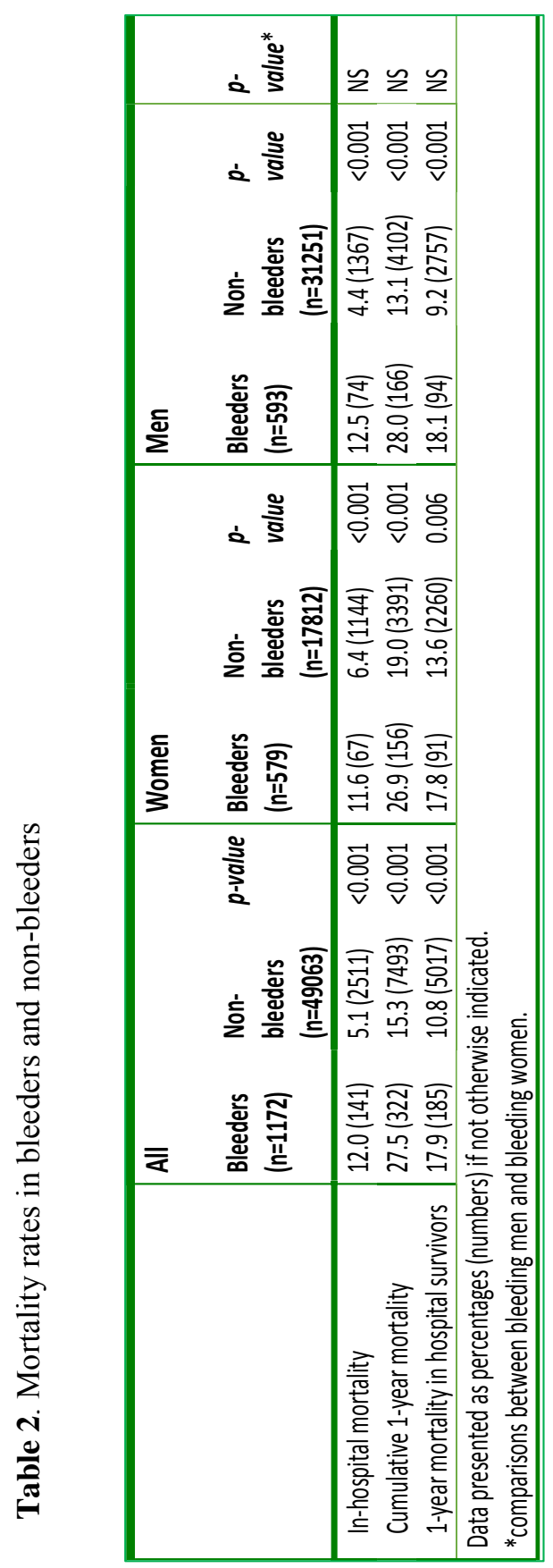




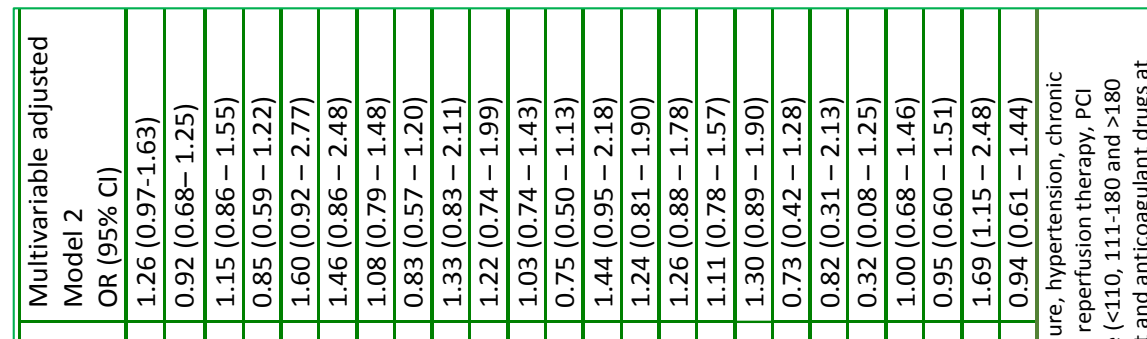

(ृ)

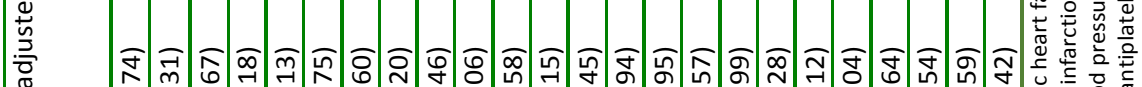

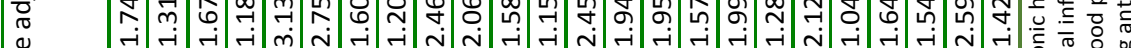

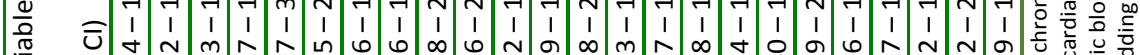

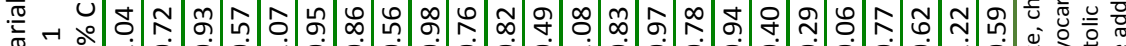

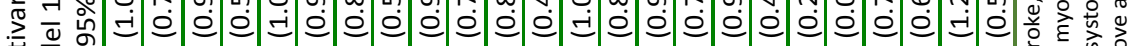

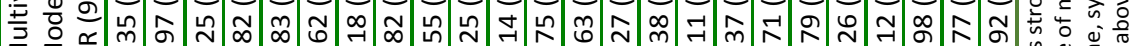

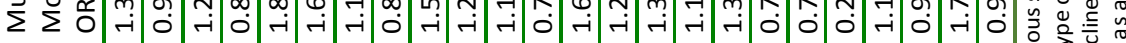

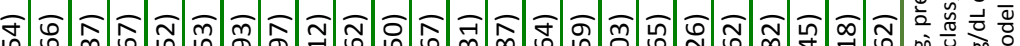

ஸุ

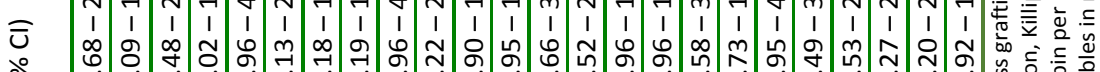

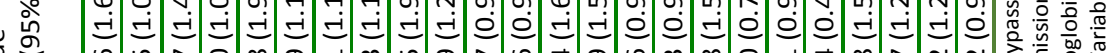

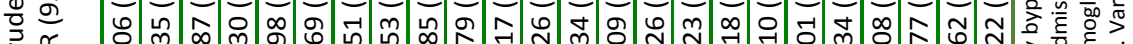

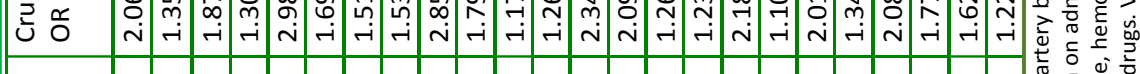

รั)

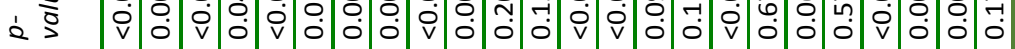

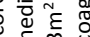

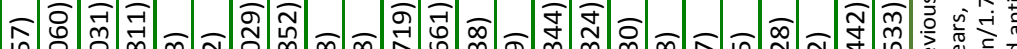

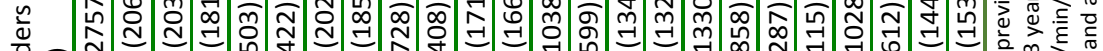

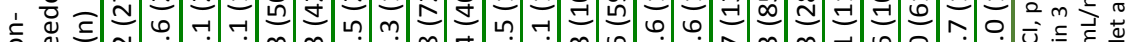

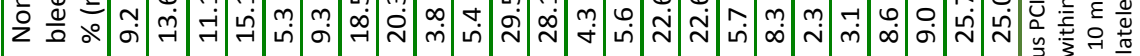

to

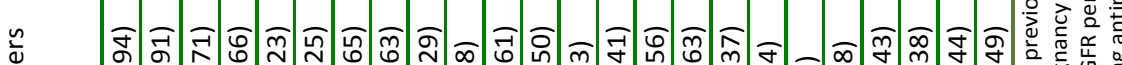

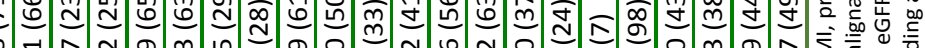

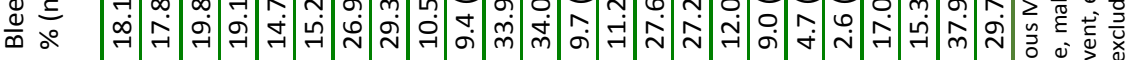

胥 
In-hospital and one-year mortality was higher in those with a bleeding complication compared with the cohort without a bleed, in both women and men. (Table 2, Figure 3) After multivariate adjustment, one-year mortality was still significantly higher, the group with a bleed versus the group without a bleed, in men (OR 1.35, 95\% CI 1.04-1.74) but not in women (OR 0.97, 95\% CI 0.72-1.31), with a significant interaction test $(\mathrm{p}<0.001)$. When discharged antiplatelet/ anticoagulant medication was added to the multivariable adjustments, the effect of bleeds was further attenuated and no longer significant.(Table 3) Also, in STEMI patients and in patients with an angiography performed, the adjusted risk increase associated with in-hospital bleeds was significant in men but not in women. Men with a bleed had almost a doubled risk of long-term mortality compared with men without a bleed in STEMI; whereas in NSTEMI the risk increase associated with bleeds was not statistically significant. Among age subgroups, the adjusted risk increase associated with bleeding events was found only in the oldest group of men.

However, among the cohort with bleeding complications, there were no gender differences in mortality, neither in-hospital ( $11.6 \%$ vs. $12.5 \%, \mathrm{p}=0.63)$ nor at one year $(26.9 \%$ vs. $28.0 \%, \mathrm{p}=0.69)$. (Table 2$)$
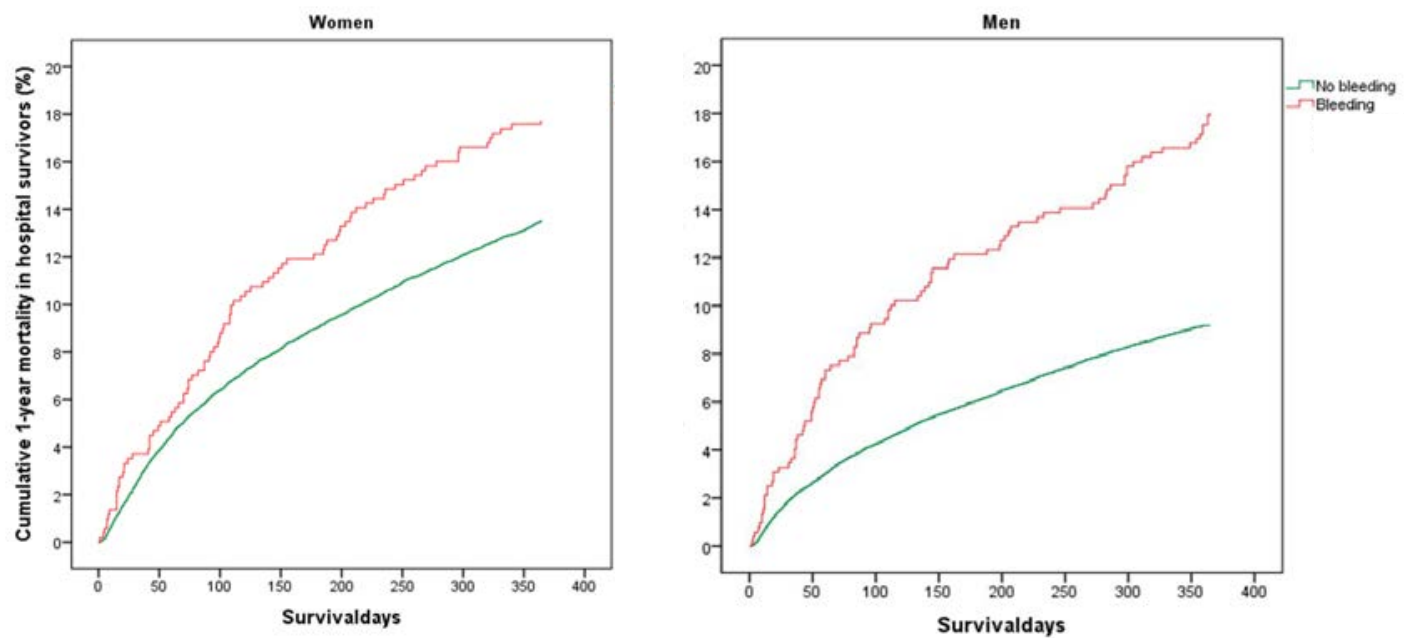

Figure 3. One-year mortality in bleeders vs non-bleeders, men and women separated, crude data. Log rank test, $\mathrm{p}<0.001$ in both genders. 


\section{Paper II}

\section{Baseline characteristics}

In this observational study with a thorough search of patient files, in a total 850 patients with MI were included (37.8\% women) and followed for one year.

We found that bleeding men had lower body weight and lower eGFR compared to non-bleeding men. There were no significant differences in risk factors, comorbidities or medication on admission between male bleeders and non-bleeders.

There were no significant differences in baseline features, medication on admission or comorbidities between female bleeders and non-bleeders except for a higher incidence of previous gastrointestinal ulcer among the women with bleeding complications.

When comparing bleeding men with bleeding women, women were older and had a lower body weight, lower haemoglobin values and lower eGFR, but higher heart rate. Women more often had a history of hypertension and they were more often treated with diuretics on admission.

\section{Interventions and medications at discharge}

Among men the bleeding population had less PCI performed but more often CABG compared to the non-bleeders. Treatment with LMWH was associated with bleeding complications whereas GPIIB/IIIa inhibitors was not. Men with a bleeding complication less often were discharged with ADP-receptor inhibitors and acetylsalicylic acid (ASA), but more often with protonpump inhibitors (PPI). Among the female cohort bleeding women tended to have PCI performed more often compared to non-bleeding women. Treatment with LMWH and GPIIb/IIIa inhibitors were both associated with bleeding complications. Bleeding women were more often discharged with PPIs and histamine 2 (H2) antagonists, but with similar use of platelet inhibitors compared to non-bleeders.

When comparing bleeding men with bleeding women, women with bleeding complications more often had PCI performed, but less often with CABG compared to the bleeding men. Female bleeders were also more often discharged with selective serotonin reuptake inhibitors (SSRIs) and $\mathrm{H} 2$ antagonists compared to men with bleeding complications.

\section{Bleeding events and prognostic impact}

The incidence of in-hospital bleeding complications comprised about half of the bleeding events, $13.2 \%$ (112), with no significant difference between men and women. The majority of in-hospital bleeds were non-surgery related. The majority of in-hospital bleeding complications were non-surgery related, 13.1 vs $10.0 \%$ $(\mathrm{p}=0.2)$ for women and men respectively. Women had significantly more major/minor non-surgery related bleeding complications than men $(6.3$ vs $3.1 \%$, $\mathrm{p}=0.03$ ). (Table 4, Figure 4). 
From discharge to end of follow-up 13.5\% (115) of the patients experienced a bleeding complication. The majority of long-term bleeding complications were non-surgery related $(11.7 \%)$, occurring significantly more often in women than in men (14.7 vs. $9.7 \%, \mathrm{p}=0.03)$. (Table 5).

Table 4. Incidence of bleedings, divided according to TIMI classification.

\begin{tabular}{|c|c|c|c|c|}
\hline & $\begin{array}{l}\text { Bleedings all } \\
\text { patients } \\
(n=850)\end{array}$ & $\begin{array}{l}\text { Bleedings } \\
\text { women } \\
(\mathbf{n}=321)\end{array}$ & $\begin{array}{l}\text { Bleedings men } \\
(\mathrm{n}=529)\end{array}$ & p-value \\
\hline \multicolumn{5}{|c|}{ In-hospital bleedings } \\
\hline all & $13.2(112)$ & $13.4(43)$ & $13.0(69)$ & NS \\
\hline major + minor & $6.2(53)$ & $6.5(21)$ & $6.0(32)$ & NS \\
\hline major & $2.0(17)$ & $1.2(4)$ & $2.5(13)$ & NS \\
\hline minor & $4.2(36)$ & $5.3(17)$ & $3.6(19)$ & NS \\
\hline minimal & $6.9(59)$ & $6.9(22)$ & $7.0(37)$ & NS \\
\hline \multicolumn{5}{|c|}{ Non-surgery related bleedings } \\
\hline all & $11.2(93)$ & $13.1(42)$ & $10.0(51)$ & NS \\
\hline major+minor & $4.3(36)$ & $6.3(20)$ & $3.1(16)$ & 0.03 \\
\hline major & $1.1(9)$ & $1.3(4)$ & $1.0(5)$ & NS \\
\hline minor & $3.2(27)$ & $5.0(16)$ & $2.2(11)$ & 0.02 \\
\hline minimal & $6.9(57)$ & $6.9(22)$ & $6.8(35)$ & NS \\
\hline \multicolumn{5}{|c|}{ Bleedings from discharge to end of follow-up } \\
\hline all & $13.5(115)$ & $15.3(49)$ & $12.3(65)$ & NS \\
\hline major+minor & $6.2(53)$ & $6.2(20)$ & $6.2(33)$ & NS \\
\hline major & $1.8(15)$ & $2.2(7)$ & $1.5(8)$ & NS \\
\hline minor & $4.5(38)$ & $4.0(13)$ & $4.7(25)$ & NS \\
\hline minimal & $7.3(62)$ & $9.0(29)$ & $6.2(33)$ & NS \\
\hline \multicolumn{5}{|c|}{ Non-surgery related bleedings } \\
\hline all & $11.7(97)$ & $14.7(47)$ & $9.7(50)$ & 0.03 \\
\hline major+minor & $4.6(38)$ & $5.6(18)$ & $3.9(20)$ & NS \\
\hline major & $1.3(11)$ & $1.9(6)$ & $1.0(5)$ & NS \\
\hline minor & $3.2(27)$ & $3.8(12)$ & $2.9(15)$ & NS \\
\hline minimal & $7.1(59)$ & $9.1(29)$ & $5.8(30)$ & 0.08 \\
\hline
\end{tabular}

The most common location of bleeding, in-hospital and during follow-up combined, was the gastrointestinal tract, where women had significantly more bleeding events than men ( 12.1 vs $7.6 \%, \mathrm{p}=0.03$ ).

Women also had significantly more access site bleeding events ( $4 \%$ vs $1.7 \%$, $\mathrm{p}=0.04)$, while men had more surgery related bleeding events $(6.4 \%$ vs $0.9 \%$, $\mathrm{p} \leq 0.001)$. A detailed description of bleeding locations, divided into in-hospital and follow-up bleeding complications, is presented in Figure 5. 


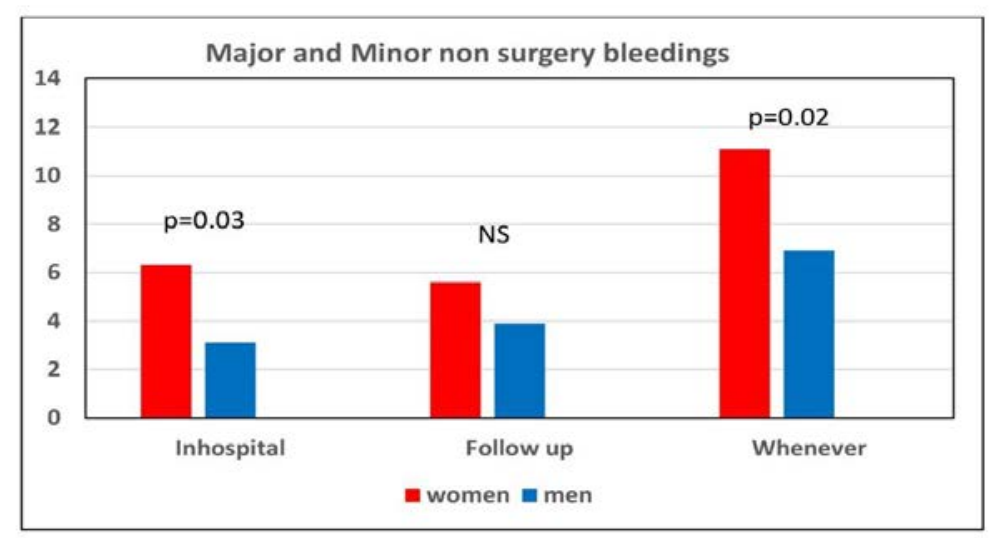

Figure 4. Major and minor non-surgery related bleeding events, TIMI criteria. Comparing men and women. Chi-square test.

Table 5. Incidence of bleedings, divided according to TIMI classification.

\begin{tabular}{|c|c|c|c|c|}
\hline & $\begin{array}{l}\text { Bleedings all } \\
\text { patients }(n=850)\end{array}$ & $\begin{array}{l}\text { Bleedings women } \\
(\mathrm{n}=321)\end{array}$ & $\begin{array}{l}\text { Bleedings men } \\
(n=529)\end{array}$ & p-value \\
\hline \multicolumn{5}{|c|}{ In-hospital bleedings } \\
\hline all & $13.2(112)$ & $13.4(43)$ & $13.0(69)$ & NS \\
\hline major+minor & $6.2(53)$ & $6.5(21)$ & $6.0(32)$ & NS \\
\hline major & $2.0(17)$ & $1.2(4)$ & $2.5(13)$ & NS \\
\hline minor & $4.2(36)$ & $5.3(17)$ & $3.6(19)$ & NS \\
\hline minimal & $6.9(59)$ & $6.9(22)$ & $7.0(37)$ & NS \\
\hline \multicolumn{5}{|c|}{ Non-surgery related bleedings } \\
\hline all & $11.2(93)$ & $13.1(42)$ & $10.0(51)$ & NS \\
\hline major+minor & $4.3(36)$ & $6.3(20)$ & $3.1(16)$ & 0.03 \\
\hline major & $1.1(9)$ & $1.3(4)$ & $1.0(5)$ & NS \\
\hline minor & $3.2(27)$ & $5.0(16)$ & $2.2(11)$ & 0.02 \\
\hline minimal & $6.9(57)$ & $6.9(22)$ & $6.8(35)$ & NS \\
\hline \multicolumn{5}{|c|}{ Bleedings from discharge to end of follow-up } \\
\hline all & $13.5(115)$ & $15.3(49)$ & $12.3(65)$ & NS \\
\hline major+minor & $6.2(53)$ & $6.2(20)$ & $6.2(33)$ & NS \\
\hline major & $1.8(15)$ & $2.2(7)$ & $1.5(8)$ & NS \\
\hline minor & $4.5(38)$ & $4.0(13)$ & $4.7(25)$ & NS \\
\hline minimal & $7.3(62)$ & $9.0(29)$ & $6.2(33)$ & NS \\
\hline \multicolumn{5}{|c|}{ Non-surgery related bleedings } \\
\hline all & $11.7(97)$ & $14.7(47)$ & $9.7(50)$ & 0.03 \\
\hline major+minor & $4.6(38)$ & $5.6(18)$ & $3.9(20)$ & NS \\
\hline major & $1.3(11)$ & $1.9(6)$ & $1.0(5)$ & NS \\
\hline minor & $3.2(27)$ & $3.8(12)$ & $2.9(15)$ & NS \\
\hline minimal & $7.1(59)$ & $9.1(29)$ & $5.8(30)$ & 0.08 \\
\hline
\end{tabular}


In regression analyses, both crude and adjusted for variables known to predict bleeding, including, age, there were no significant differences in bleeding rates between women and men.

Men with major non-surgery related bleeding events had increased mortality compared to non-bleeding men (40 vs $11.2 \%(\mathrm{p}=0.008)$ ) but otherwise there was no correlation between bleeding and death/MI in either women or men.

When analysing the association between bleeding and cessation of platelet inhibitors, we found that women stopped their platelet inhibitor drugs prematurely, because of bleeding, more often than men $(3.4 \%$ vs $1.1 \%$, $p=0.02)$.
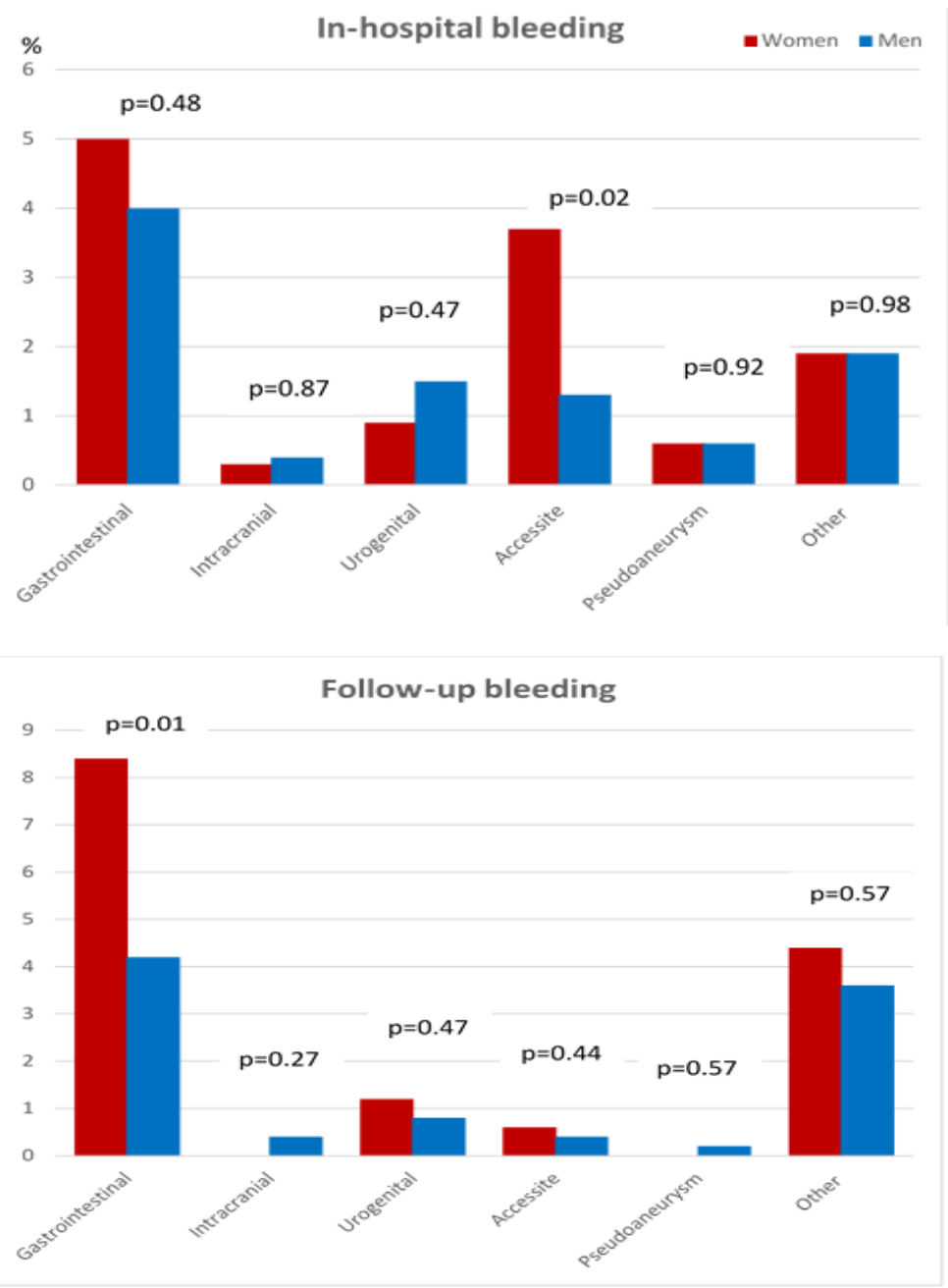

Figure 5. Bleeding locations, in-hospital and follow-up bleeding events (percentages). Comparing men and women. Chi-square test. 


\section{Paper III}

\section{Baseline characteristics}

We included 272 patients, $25.7 \%$ women. The mean age was 74.1 years and women were significantly older than men ( 77.4 vs 73.0 years, $p<0.01$.) Almost half of the population (44.9\%) had a history of ischemic heart disease and one third (34.9\%) had a previous MI. Almost a third had experienced a previous bleeding (31.6\%). A majority was already treated with OAC (almost exclusively warfarin) before the index hospitalisation $(60.3 \%)$. There were no significant differences between women and men in comorbidities except that diabetes was more prevalent in women ( 38.6 vs $26.2 \%, \mathrm{p}=0.05$ ). The only sex difference in medication on admission to hospital was use of PPIs which was more common in women ( 42.9 vs $28.7 \%, p=0.03$ ). Women had lower hemoglobin ( 129.4 vs 141.3 $\mathrm{g} / \mathrm{L}, \mathrm{p}<0.01)$ and creatinine $(87.1$ vs $103.3 \mu \mathrm{mol} / \mathrm{L}, \mathrm{p}<0.01)$ on admission. Almost all patients, $97.4 \%$, underwent coronary angiography, and $93.4 \%$ were treated with PCI. Arterial access was mostly the radial artery, $61.0 \%$. There were no significant differences between men and women in access site. (Table 6)

Table 6. Interventions and events during index hospitalisation

\begin{tabular}{|c|c|c|c|c|}
\hline & All $(n=272)$ & Women $(n=70)$ & Men $(n=202)$ & P-value \\
\hline \multicolumn{5}{|l|}{ Interventions } \\
\hline Coronary angiography & $265(97.4)$ & $67(95.7)$ & $198(98)$ & 0.38 \\
\hline PCI & $254(93.4)$ & $64(91.4)$ & $190(94.1)$ & 0.42 \\
\hline Gastroscopy & $2(0.7)$ & $0(0.0)$ & $2(1.0)$ & 1.00 \\
\hline \multicolumn{5}{|l|}{ Arterial access } \\
\hline Radial & $161(61.0)$ & $41(62.1)$ & $120(60.6)$ & \multirow{3}{*}{0.05} \\
\hline Femoral & $97(36.7)$ & $21(31.8)$ & $76(38.4)$ & \\
\hline Alternate Access site* & $6(2.3)$ & $4(6.1)$ & $2(1.0)$ & \\
\hline \multicolumn{5}{|c|}{ Bleeding during index hospitalisation } \\
\hline Any bleeding & $68(25.0)$ & $16(22.9)$ & $52(25.7)$ & 0.63 \\
\hline Transfusion & $4(1.5)$ & $3(4.2)$ & $1(0.5)$ & 0.02 \\
\hline \multicolumn{5}{|c|}{ Bleeding severity according to the TIMI classification } \\
\hline Major & $1(0.4)$ & 0 & $1(0.5)$ & \multirow{3}{*}{0.90} \\
\hline Minor & $11(4.0)$ & $3(4.3)$ & $8(4.0)$ & \\
\hline Minimal & $56(20.6)$ & $13(18.6)$ & $43(21.3)$ & \\
\hline \multicolumn{5}{|c|}{ Bleeding severity according to the BARC classification } \\
\hline Grade 3 & $3(1.1)$ & $1(1.4)$ & $2(1.0)$ & \multirow{3}{*}{0.94} \\
\hline Grade 2 & $23(8.5)$ & $5(7.1)$ & $18(8.9)$ & \\
\hline Grade 1 & $42(15.4)$ & $10(14.3)$ & $32(15.8)$ & \\
\hline \multicolumn{5}{|l|}{ Localisation of bleeding } \\
\hline Any gastrointestinal & $5(1.8)$ & $2(2.9)$ & $3(1.5)$ & \multirow{5}{*}{0.36} \\
\hline Any urogenital & $8(2.9)$ & $1(1.4)$ & $7(3.5)$ & \\
\hline $\begin{array}{l}\text { Any ICA/PCI related } \\
\text { bleeding }\end{array}$ & $38(14.0)$ & $7(10.0)$ & $31(15.3)$ & \\
\hline Any surgery related bleeding & $1(0.4)$ & $1(1.4)$ & 0 & \\
\hline Other bleeding location\# & $16(5.9)$ & $11(5.4)$ & $5(7.1)$ & \\
\hline
\end{tabular}




\section{Indications and duration of DAPT and OAC}

The most common indication for DAPT at inclusion in the study and discharge from hospital was NSTEMI and STEMI, NSTEMI were more common in women compared to men and STEMI were more common in men compared to women.

The leading indication for $\mathrm{OAC}$ were $\mathrm{AF}$, followed by venous thromboembolism (VTE) and mural thrombus. There were no differences between the sexes with regard to indication for OAC.

Most patients ( $61.8 \%$ ) were planned for $\leq 1$ month of TAT followed by 11 months of the combination of aspirin and OAC, followed by only OAC. The use of direct acting OAC (DOAC) was very low whereas $97.1 \%$ were discharged with warfarin. Clopidogrel was used almost exclusively as P2Y12-inhibitor, with 7 cases $(2.6 \%)$ using ticagrelor and none using prasugrel. There were no sex differences in planned TAT duration.

Discontinuation of TAT earlier than intended was done in 110 patients (40.4\%), more often in women than in men ( 52.9 vs $36.1 \%, \mathrm{p}=0.01)$. In 31 patients (11.4\%) the P2Y12-inhibitor was discontinued, and women discontinued the P2Y12-inhibitors more often than men (17.1 vs 9.4\%, $\mathrm{p}=0.08)$. In 44 patients $(16.2 \%)$ aspirin was discontinued, which was significantly more common in women than in men ( 25.7 vs $12.9 \%, \mathrm{p}=0.01)$. In 91 patients $(33.5 \%)$ OAC was stopped in advance, without any sex difference ( 37.1 vs $32.2 \%, p=0.45$ ).

Bleeding was the most common reason why TAT was stopped in both women and men, explaining $45.9 \%$ and $43.8 \%(\mathrm{p}=0.83)$ of discontinued TAT treatment, respectively. (Table 7) 
Table 7. Therapy at discharge and premature discontinuation of TAT

\begin{tabular}{|c|c|c|c|c|}
\hline & $\begin{array}{l}\text { All } \\
(n=272)\end{array}$ & $\begin{array}{l}\text { Women } \\
(\mathbf{n}=70)\end{array}$ & $\begin{array}{l}\text { Men } \\
(n=202)\end{array}$ & P-value \\
\hline \multicolumn{5}{|c|}{ Type of antiplatelet and oral anticoagulant agents in TAT at discharge* } \\
\hline Aspirin & $272(100)$ & $70(100)$ & $203(100)$ & NA \\
\hline Clopidogrel & $265(97.4)$ & $68(97.1)$ & $197(97.5)$ & 1.00 \\
\hline Ticagrelor & $7(2.6)$ & $2(2.9)$ & $5(2.5)$ & 1.00 \\
\hline Warfarin & $264(97.1)$ & $67(95.7)$ & $197(97.5)$ & 0.43 \\
\hline Apixaban & $6(2.2)$ & $2(2.9)$ & $4(2.0)$ & 0.65 \\
\hline Rivaroxaban & $2(0.7)$ & $1(1.4)$ & $1(0.5)$ & 0.45 \\
\hline \multicolumn{5}{|c|}{ Other medication at discharge } \\
\hline NSAID & 0 & 0 & 0 & NA \\
\hline PPI & $138(50.7)$ & $44(62.9)$ & $94(46.5)$ & 0.02 \\
\hline \multicolumn{5}{|l|}{ Planned duration of TAT } \\
\hline$\leq 1$ month & $168(61.8)$ & $47(67.1)$ & $121(59.9)$ & \multirow{4}{*}{0.22} \\
\hline $1-3$ months & $75(27.6)$ & $17(24.3)$ & $58(28.7)$ & \\
\hline $3-6$ months & $27(9.9)$ & $5(7.1)$ & $22(10.9)$ & \\
\hline 6-12 months & $2(0.7)$ & $1(1.4)$ & $1(0.5)$ & \\
\hline \multicolumn{5}{|c|}{ Discontinuation or interruption of TAT\# } \\
\hline Any discontinuation & $110(40.4)$ & $37(52.9)$ & $73(36.1)$ & 0.01 \\
\hline Aspirin discontinuation & $44(16.2)$ & $18(25.7)$ & $26(12.9)$ & 0.01 \\
\hline $\begin{array}{l}\text { P2Y12-inhibitor } \\
\text { discontinuation }\end{array}$ & $31(11.4)$ & $12(17.1)$ & $19(9.4)$ & 0.08 \\
\hline OAC discontinuation & $91(33.5)$ & $26(37.1)$ & $65(32.2)$ & 0.45 \\
\hline \multicolumn{5}{|c|}{ Reason of discontinuation or interruption of TAT } \\
\hline Gastric symptoms & $3(2.7)$ & $3(8.1)$ & 0 & 0.01 \\
\hline Bleeding & $49(44.5)$ & $17(45.9)$ & $32(43.8)$ & 0.83 \\
\hline Allergic reaction & $2(1.8)$ & 0 & $2(2.7)$ & 0.55 \\
\hline Coronary angiography/PCI & $20(18.2)$ & $5(13.5)$ & $15(20.5)$ & 0.37 \\
\hline Surgery & $20(18.2)$ & $5(13.5)$ & $15(20.5)$ & 0.37 \\
\hline \multicolumn{5}{|c|}{$\begin{array}{l}\text { Figures presented as numbers (counts) if not otherwise specified. *No patient received prasugrel, } \\
\text { dabigatran or endoxaban at discharge. \#Among patients that interrupted or discontinued TAT. } \\
\text { TAT= Triple Antithrombotic Therapy; OAC =Oral Anticoagulant; } \text { GI=Gastrointestinal; } \\
P C I=\text { Percutaneous Coronary Intervention; CABG=Coronary Artery Bypass Grafting; } \\
\text { TIMI=Thrombolysis in Myocardial Infarction; BARC=Bleeding Academic Research Consortium. } \\
* T \text { Two interventions. }\end{array}$} \\
\hline
\end{tabular}

\section{Bleeding events}

During index hospitalization, a quarter of the patients $(25.0 \%)$ experienced at least one bleeding event. More than half of these, 55.9\% were related to angiography or PCI. Most of these bleeding episodes were classified as minimal according to the TIMI bleeding scale $(82.4 \%)$ or BARC 1 grade $(61.8 \%)$. No significant difference in bleeding location or severity grade was found between women and men. (Table 6)

During follow-up a total of 40.1\% (109) had at least one bleeding event. Seventyeight patients had one bleeding event whereas remaining 31 patients had up to 4 bleeding events. Although a numerically higher rate of bleeding was found in 
women ( 48.6 vs $37.1 \%$. $p=0.09)$ there was no significant difference between men and women.

Regarding severity, sixteen patients (5.9\%) experienced a TIMI major bleeding, and $61(22.8 \%)$ a TIMI minor bleeding during follow-up. According to the BARC classification $1.5 \%$ experienced a BARC $4-5$ bleeding and $9.6 \%$ a BARC 3 bleeding. Gastrointestinal bleeds occurred in 13.6\%, intracranial bleeds in $2.2 \%$, urogenital bleeds in $5.1 \%$, surgery related bleeds in $2.2 \%$ and bleeds related to coronary angiography and/or PCI in 3.3\% of the patients. There were no sex differences in bleeding severity or bleeding location except gastrointestinal, which occurred more often in women than in men, $20.0 \%$ vs $11.4 \%, p=0.07$. During the one-year follow-up 156 bleeding events were registered, 109 in men and 47 in women. Among these TIMI minor and BARC 2 were the most common severity grades (50.0 and $60.2 \%$, respectively), and $46.8 \%$ were less serious bleeds such as epistaxis and hematomas, followed by bleeds from the gastrointestinal tract (28.8\%), and urogenital bleeds $(9.0 \%)$. Six bleeds $(3.8 \%)$ were intracranial, five men and one woman. (Table 8 )

In total $54.4 \%$ (58.6\% women, $53.0 \%$ men, $\mathrm{p}=0.41)$ experienced a bleeding during or within one year after the index event.

\section{Ischemic events and mortality during follow-up}

In total, 49 patients (18.0\%) experienced at least one coronary event during the follow-up period ( 36 men, 13 women), and $13.2 \%$ experienced 2 or more events. In $30.6 \%$ a bleeding event proceeded the new coronary event. Among all 72 coronary events UAP was the most common type (38.9\%) followed by stable coronary artery disease (SCAD) (34.7\%), whereas NSTEMI and STEMI represented $22.2 \%$ and $2.8 \%$, respectively. The most common coronary event in women was SCAD (61.5\%) whereas UAP was the most common event in men $(63.8 \%)$. Twelve patients underwent PCI ( 2 women and 10 men). Although men had numerously more coronary events and PCI performed there was no significant difference between men and women. Stroke or transient ischemic attack (TIA) affected $2.9 \%$ of all patients during follow-up, without any differences between men and women.

Twenty patients died during the one-year follow-up, $11.4 \%$ women and $5.9 \%$ men ( $\mathrm{p}=0.13$ ). Thirteen of these patients had suffered at least one bleeding complication during index hospitalisation or after discharge. 
Table 8. Bleeding and ischemic events during follow-up.

\begin{tabular}{|c|c|c|c|c|}
\hline & All (n=272) & Women $(n=70)$ & Men $(n=202)$ & P-value \\
\hline \multicolumn{5}{|l|}{ Bleeding during follow-up } \\
\hline Any bleeding & $109(40.1)$ & $34(48.6)$ & $75(37.1)$ & 0.09 \\
\hline \multicolumn{5}{|c|}{ Number of bleeds during follow-up } \\
\hline One & $78(28.7)$ & $24(34.3)$ & $54(26.7)$ & \multirow{4}{*}{0.38} \\
\hline Two & $18(6.6)$ & $7(10.0)$ & $11(5.4)$ & \\
\hline Three & $10(3.7)$ & $3(4.3)$ & $7(3.5)$ & \\
\hline Four & $3(1.1)$ & 0 & $3(1.5)$ & \\
\hline \multicolumn{5}{|l|}{ Therapy at first bleeding event } \\
\hline Triple Antithrombotic Therapy & $52(47.7)$ & $15(44.1)$ & $37(49.3)$ & \multirow{7}{*}{0.45} \\
\hline Dual Antiplatelet Therapy & $2(1.8)$ & $1(2.9)$ & $1(1.3)$ & \\
\hline Aspirin and $\mathrm{OAC}$ & $48(44.0)$ & $17(50.0)$ & $31(41.3)$ & \\
\hline $\mathrm{P} 2 \mathrm{Y}^{12}$-inhibitor and $\mathrm{OAC}$ & $1(0.9)$ & $1(2.9)$ & 0 & \\
\hline Aspirin, single therapy & $2(1.8)$ & 0 & $2(2.7)$ & \\
\hline $\mathrm{P} 2 \mathrm{Y}^{12}$-inhibitor, single therapy & 0 & 0 & 0 & \\
\hline OAC, single therapy & $1(0.9)$ & 0 & $1(1.3)$ & \\
\hline \multicolumn{5}{|c|}{ Any bleeding during follow-up according to the TIMI classification } \\
\hline Major & $16(5.9)$ & $3(4.3)$ & $13(6.4)$ & 0.51 \\
\hline Minor & $62(22.8)$ & $19(27.1)$ & $43(21.3)$ & 0.31 \\
\hline Minimal & $46(16.9)$ & $16(22.9)$ & $30(14.9)$ & 0.12 \\
\hline \multicolumn{5}{|c|}{ Any bleeding during follow-up according to the BARC classification } \\
\hline BARC 5 & $3(1.1)$ & 0 & $3(1.5)$ & 0.57 \\
\hline BARC 4 & $1(0.4)$ & 0 & $1(0.5)$ & 0.56 \\
\hline BARC 3 & $26(9.6)$ & $7(10.0)$ & $19(9.4)$ & 0.88 \\
\hline BARC 2 & $72(26.5)$ & $23(32.9)$ & $49(24.3)$ & 0.16 \\
\hline BARC 1 & $24(8.8)$ & $10(14.3)$ & $14(6.9)$ & 0.06 \\
\hline \multicolumn{5}{|c|}{$\begin{array}{l}\text { Localization of bleeding } \\
\text { Any bleeding with the following localization; }\end{array}$} \\
\hline Intracranial & $6(2.2)$ & $1(1.4)$ & $5(2.5)$ & 1.00 \\
\hline Gastrointestinal & $37(13.6)$ & $14(20.0)$ & $23(11.4)$ & 0.07 \\
\hline Urogenital & $14(5.1)$ & $1(1.4)$ & $13(6.4)$ & 0.13 \\
\hline ICA/PCI related & $9(3.3)$ & $2(2.9)$ & $7(3.5)$ & 1.00 \\
\hline Surgery related & $6(2.2)$ & 0 & $6(3.0)$ & 0.34 \\
\hline Other location* & $60(22.1)$ & $20(30.0)$ & $40(19.3)$ & 0.06 \\
\hline \multicolumn{5}{|c|}{ Ischemic Events during follow-up } \\
\hline Any coronary event & $49(18.0)$ & $13(18.6)$ & $36(17.8)$ & 0.89 \\
\hline Stable CAD & $23(8.5)$ & $7(10.0)$ & $16(7.9)$ & 0.59 \\
\hline UAP & $20(7.4)$ & $4(5,7)$ & $16(7.9)$ & 0.54 \\
\hline NSTEMI & $12(4.4)$ & $4(5.7)$ & $12(4.4)$ & 0.54 \\
\hline STEMI & $2(0.7)$ & $1(1.4)$ & $1(0.5)$ & 0.45 \\
\hline PCI & $15(5.5)$ & $3(4.3)$ & $12(5.9)$ & 0.65 \\
\hline stroke/TIA & $8(2.9)$ & $2(2.9)$ & $6(3.0)$ & 1.00 \\
\hline \multicolumn{5}{|l|}{ Mortality } \\
\hline Dead during follow-up & $20(7.4)$ & $8(11.4)$ & $12(5.9)$ & 0.13 \\
\hline \multicolumn{5}{|c|}{$\begin{array}{l}\text { Figures presented as numbers (counts) if not otherwise specified. *Mostly epistaxis or hematomas. OAC }=\text { Oral Antico- } \\
\text { agulant; TIMI=Thrombolysis in Myocardial Infarction; BARC=Bleeding Academic Research Consortium; SCAD=Sta- } \\
\text { ble Coronary Artery Disease; UAP=Unstable Angina Pectoris; NSTEMI= Non ST-Elevation Myocardial Infarction; } \\
\text { STEMI=ST-Elevation Myocardial Infarction; PCI=Percutaneous Coronary Intervention }\end{array}$} \\
\hline
\end{tabular}




\section{Costs of bleeding events}

The per patient mean health care costs were EUR 5787 and EUR 575 for bleeders and non-bleeders respectively during the follow-up period. In the bleeding group EUR 3235 were associated with bleeding with certainty. Health care costs were similar for men and women with bleeding during follow-up, EUR 5895 and EUR 5540 , respectively. For the non-bleeders corresponding figures were EUR 695 and EUR 145 for men and women, respectively. (Table 9)

Table 9. Unit costs and one-year health care costs in bleeders and non-bleeders, EUR, Euro

\begin{tabular}{|c|c|c|c|c|c|c|}
\hline & Unit costs & $\begin{array}{l}\text { No bleed- } \\
\text { ing }\end{array}$ & & Bleeding & & $\begin{array}{l}\text { Differ- } \\
\text { ence }\end{array}$ \\
\hline & & $\mathrm{n}=162$ & & $\mathrm{n}=110$ & & (bleeders \\
\hline Resource use & & Mean & SEM & Mean & SEM & $\begin{array}{l}\text { vs not } \\
\text { bleeders) }\end{array}$ \\
\hline \multicolumn{7}{|l|}{ Bleeding defined } \\
\hline Hospitalization due to bleeding & $376 ; 547 *$ & 0 & 0 & 2893 & 518 & \\
\hline $\begin{array}{l}\text { Bleeding during hospitaliza- } \\
\text { tion** }\end{array}$ & $547 * * *$ & 0 & 0 & 56 & 21 & \\
\hline $\begin{array}{l}\text { Outpatient care visit due to } \\
\text { bleeding }\end{array}$ & 312 & 0 & 0 & 192 & 21 & 192 \\
\hline Blood products & 101 & 0 & 0 & 104 & 21 & 104 \\
\hline Cost bleeding defined & & 0 & 0 & 3236 & 517 & 3236 \\
\hline \multicolumn{7}{|c|}{ Costs Not necessarily due to bleedings**** } \\
\hline Hospitalization due to ACS & $376 ; 547 *$ & 314 & 80 & 1934 & 638 & 1620 \\
\hline Sigmoidoscopy & 456 & 0 & 0 & 17 & 8 & 17 \\
\hline Rectoscopy & 456 & 6 & 4 & 80 & 19 & 74 \\
\hline Colonoscopy & 587 & 7 & 5 & 38 & 14 & 31 \\
\hline Gastroscopy & 456 & 8 & 5 & 126 & 23 & 117 \\
\hline CABG & 6476 & 80 & 56 & 118 & 84 & 39 \\
\hline PCI & 3255 & 160 & 55 & 239 & 82 & 79 \\
\hline $\begin{array}{l}\text { Cost not necessarily due to } \\
\text { bleeding }\end{array}$ & & 575 & 113 & 2553 & 721 & 1978 \\
\hline Total costs & & 575 & 113 & 5790 & 928 & 5215 \\
\hline \multicolumn{7}{|c|}{$\begin{array}{l}\text { SEM, Standard Error of the Mean. *Hospitalizations are costed by } 376 \text { EUR plus } 547 \text { EUR per bed day. } \\
* * \text { Bleeding related cost during hospitalization for other reason than bleeding or ACS. } * * * \text { Per bed day associ- } \\
\text { ated with the bleeding. } \\
* * * * \text { Of which some may be related to bleeding but not collected solely as a bleeding event }\end{array}$} \\
\hline
\end{tabular}




\section{Paper IV}

\section{Baseline characteristics, interventions and medications}

We included 125 patients, 37 women and 88 men; median age was 67 years (67 years for women and 67.5 years for men).

A majority of the patients were admitted with STEMI, $67.6 \%$ of women and $54.5 \%$ of men, $\mathrm{p}=0.18$. There were no significant differences between men and women in baseline features or comorbidities except that diabetes were more prevalent in women. Women had significantly lower hemoglobin value and eGFR, on admission. Women also had significantly higher platelet count on admission. There were no significant differences between women and men according medication on admission.

Coronary angiography was performed in all but two patients (37 women and 86 men), $81.5 \%$ underwent PCI ( $83.5 \%$ of the women vs $80.5 \%$ of the men, $\mathrm{p}=0.66)$. During PCI, $56.8 \%$ ( $64.9 \%$ women vs $53.4 \%$ men, $\mathrm{p}=0.24)$ were treated with a GP IIb/IIIa-inhibitor (abciximab). In conjunction with angiography and/or PCI $84.8 \%$ were treated with heparin $(86.5 \%$ women vs $84.1 \%$ men, $p=0.73)$. At discharge $91.1 \%$ of the patients were treated with clopidogrel $(89.2 \%$ of women vs $92.0 \%$ of men, $\mathrm{p}=0.73$ ) and $100 \%$ with acetylsalicylic acid. There were no significant differences between women and men in medications at discharge except that men were discharged more often with statins $(100 \%$ vs $94.6 \%, p=0.03)$ and women were discharged more often with diuretics $(27 \%$ vs $11.4 \%, \mathrm{p}=0.03)$.

\section{Bleeding complications}

Women experienced significantly more bleeding complications than men $(18.9 \%$ vs $6.8 \%, \mathrm{p}=0.04$ ), during hospital stay. The majority of bleeds were minimal, according to the TIMI classification.

From discharge, over six months follow-up, the very few bleeding events occurred more often in women, but without statistical significance. ( $8.1 \%$ vs $2.3 \%$ bleeding events, $\mathrm{p}=0.13$ ).

\section{Platelet aggregation at different time points}

There were no significant differences in impedance aggregation values at any of the prespecified time-points (the presented time-points are related to LD of clopidigrel).

Among the 66 STEMI patients treated with the GP IIb/IIIa-inhibitor abciximab, there were no sex specific differences in TRAP-induced aggregation 6-8 hours, 3 days or 7-9 days after LD. (Figure 6)

We assessed ADP-induced platelet aggregation 6-8 hours, 3 days, 7-9 days and six months after LD in patients not treated with GP IIIb/IIIa inhibitors and observed no differences between women and men. (Figure 7)

To further examine the proportion of patients with a higher effect of clopidogrel, we assessed the proportion of patients with LRPR, OPR and HRPR. Again, we did not observe any difference between the sexes, neither at 3 days nor at 7-9 days. 
6-8 hours after LD

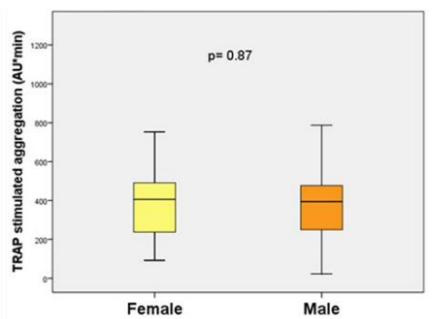

3 days after $\mathrm{LD}$

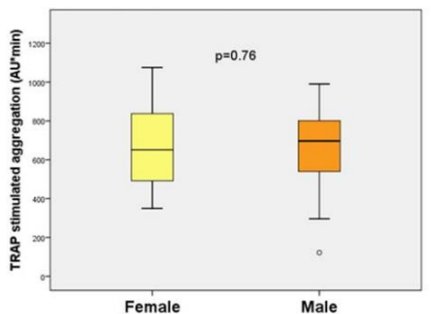

7-9 days after LD

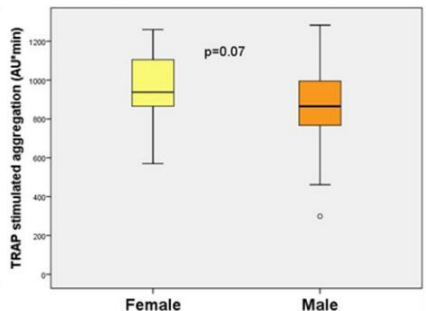

Figure 6. Thrombin receptor activating peptide (TRAP) induced platelet aggregation at three different time-points, expressed as $\mathrm{AU}^{*}$ min. Median values are reported and statistical significance between women and men was tested with the Mann-Whitney U test. LD, loading dose.

6-8 hours after LD

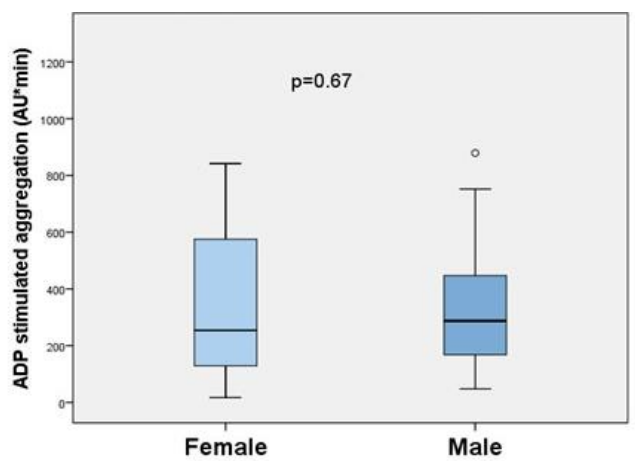

7-9 days after LD

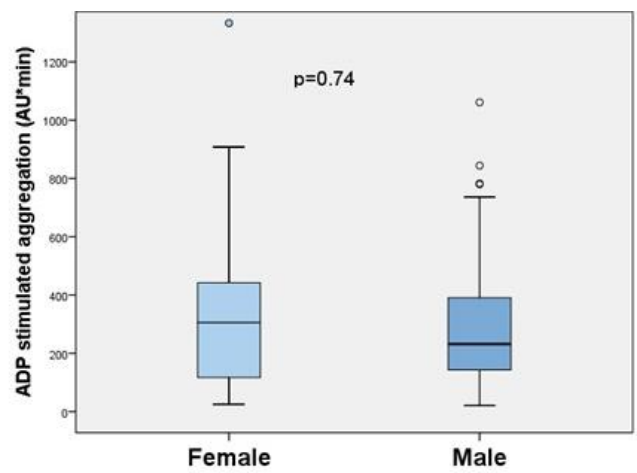

3 days after $\mathrm{LD}$

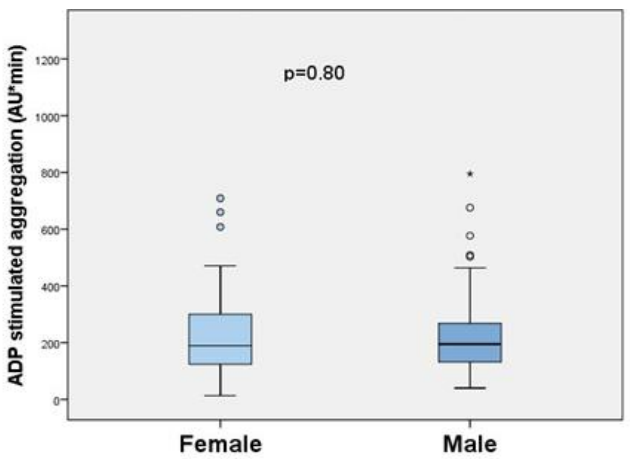

6 months after LD

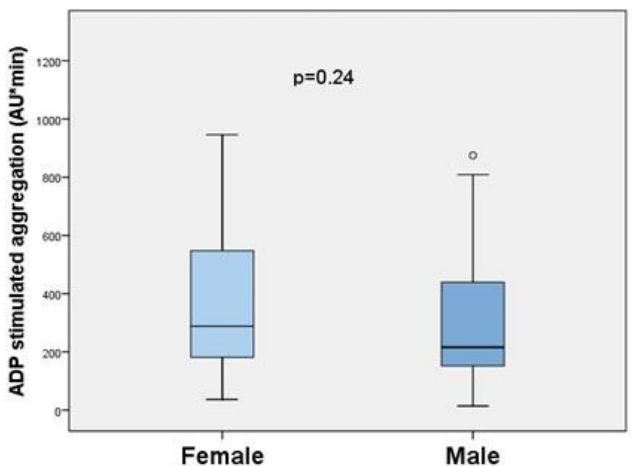

Figure 7. Adenosine diphosphate (ADP) induced platelet aggregation at four different time-points, expressed as AU*min. Median values are reported and statistical significance between women and men was tested with the Mann-Whitney U test. LD, loading dose Finally, we assessed ASPI-induced aggregation at four time-points. We found similar aggregation levels between women and men at 6-8 hours, 3 days, 7-9 days and six months after LD (Figure 8) 
6-8 hours after LD

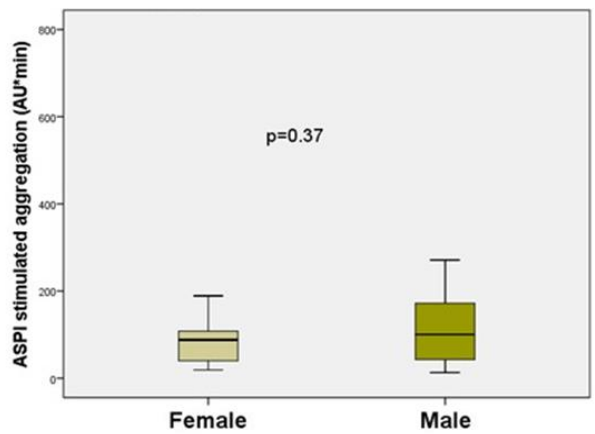

7-9 days after LD

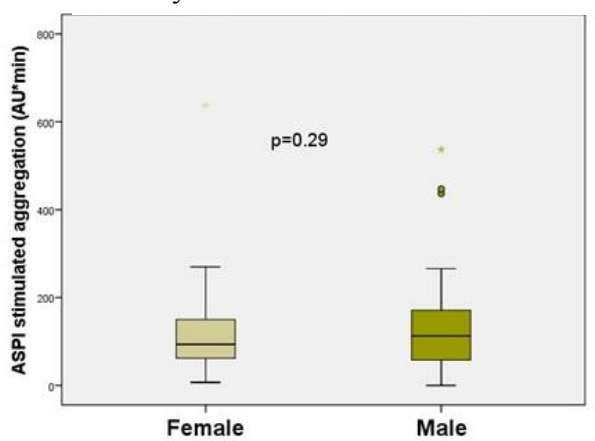

3 days after $L D$

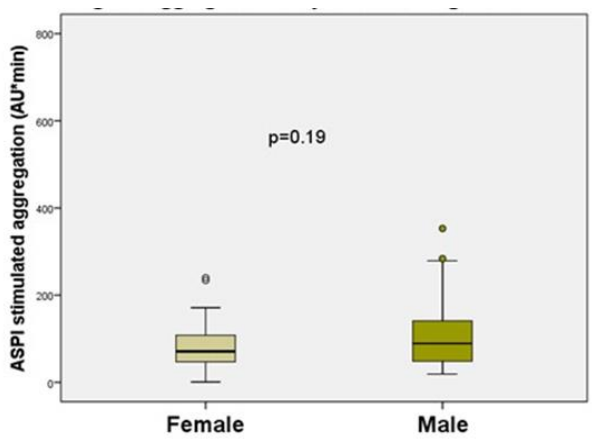

6 months after LD

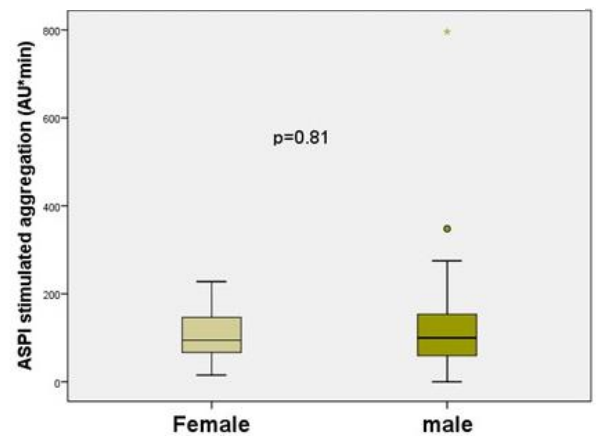

Figure 8. Arachidonic acid (ASPI) induced platelet aggregation at four different timepoints, expressed as $\mathrm{AU}^{*}$ min. Median values are reported and statistical significance between women and men was tested with the Mann-Whitney U test. LD, loading dose.

\section{Soluble p-selectin}

To further explore differences in platelet activity, we measured soluble p-selectin, which functions as a cell adhesion molecule on the surface on activated platelets. Three days after admission there was no difference in levels of p-selectin in plasma between men and women ( $28 \mathrm{vs} 28 \mathrm{ng} / \mathrm{mL}, \mathrm{p}=0$. 


\section{DISCUSSION}

The main focus of this thesis was to address the problems of bleeding complications in a population of patients in a cardiological ward, focusing on patients with ACS. Can we support the theory that women bleed more than men and also give a more detailed picture about localisation, severity, prognosis and possible explanatory variables. This thesis is based on observational findings from registries and medical journals. It is previously known that the bleeding incidence in general and among women especially is higher in randomised trials as compared to observational studies. Probably because the participants in randomised trials usually are younger and healthier. (107) Women, compared to men, are older when they are diagnosed with coronary artery disease (CAD) and as a result of this, even less women are included in the randomised trials. A study by Melloni et al presented that among over 800000 patients included in 156 cardiovascular trials there were about $30 \%$ women and only one third of the trials reported sexbased results, (108) this itself constitutes a great problem. If we ever are going to completely understand the differences between women and men more women must be included in the large randomised trials.

The major findings in all four papers are consistent. Women bleed numerously more than men but seem to have more minor or minimal bleeds and seem to withstand bleeding complications better. Men have more major bleeds and the prognostic impact of bleeding complications seem to be worse among the male patients. Interestingly and to our knowledge not previously described, the study findings point to the fact that female and male bleeders are of somewhat different kind, men with a bleeding complication are older and have more comorbidities compared to men without bleeding events while this is not the case in the female cohort. Women with bleeding complications have more angiography and PCI performed and more access site bleeds, while men with bleeds have less angiography and PCI performed pointing to an older population with more comorbidities and contraindications against interventions.

In paper I we observed that higher incidence of bleeding complications in women appeared to be restricted to patients with GFR $\geqslant 60 \mathrm{ml} / \mathrm{min}$ per $1.73 \mathrm{~m} 2$, and to patients $\leqslant 65$ years. To our knowledge, this has not been shown before and deserves further studies.

The major knowledge gap today is why women bleed more than men, though several hypotheses have been brought in to the light, the disparities between men and women still remain unclear.

\section{General background characteristics}

It has been put forward as an explanation for women's excess bleeds that they have lower body mass index (BMI), are older with worse renal function and more comorbidities.(107) These differences may indicate sex-specific biological variations affecting thrombosis and bleeding risk. (109) (Figure 9) 
In this thesis we can partially confirm this. Women were older, with lower body weight and worse renal function. Anyhow, interestingly this is not the case when comparing within each sex specific group. Bleeding men have significant differences in background characteristics such as age, weight and comorbidities compared to non-bleeding men, while this is not the case in the female group, when comparing bleeding women with non-bleeding women there are no significant differences. This finding is consistent through this thesis though less obvious in the studies with smaller cohorts. To my knowledge this is novel information. One theory that might explain this is that women are about five to ten years older, as compared to men, when they present with ACS $(110,111)$ and also about $60 \%$ of patients with MI are men (112), thus the age distribution among the females are not as wide as in the male cohort. This gives men a broader scope in age and comorbidities. The men that suffers from bleeding complications are an aged population with several comorbidities and may be more fragile. Women also live longer than men and maybe seem to be healthier in these ages. Another explanation could be that women are more prone to bleeding throughout life and soforth withstand a bleeding complication better than men, the reason for this is still benighted.

Men and women have in several large randomised trials shown similar benefits from antithrombotic therapy with both clopidogrel (73) and ticagrelor.(10, 113) TRITON-TIMI 38 is the only study showing that prasugrel had greater reduction in adverse cardiovascular events in men than women compared with clopidogrel.(9) In a recent review by Wang et al they concluded that there is to date no evidence of sex differences in effectiveness of anticoagulant therapy. (114) Yet women are still at higher risk for bleeding complications.(114)

\section{Bleeding, type of $\mathrm{Ml}$ and interventions}

Overall our data support that most $(18,87,88,115)$ but not all $(116)$ prior studies of sex differences in short-term bleeding have shown higher incidence in women, also after adjustment for baseline differences. In paper I the bleeding incidence was more than doubled in women as compared with men in the STEMI group, in accordance with a publication from the HORIZONS-AMI trial on STEMI patients that also showed twice the risk of bleeding in women compared with men. (117) Higher bleeding incidence in women with STEMI may be due to the use of more potent antithrombotic drugs in STEMI. Female gender has been linked to an increased bleeding risk with antithrombotic agents including fibrinolytics, (118)unfractionated heparin (UFH), low molecular weight heparin (LMWH) and glycoprotein inhibitors (GPIs), (119) hypothetically, partly attributable to excess dosing. (120) Excess dosing of antithrombotic medication in women has emanated from theories about an increased reactivity in women's platelets and hence a greater inhibition with platelet inhibiting drugs but also from thoughts about lower BMI and differences in female lean fat tissue and the distribution of drugs. (107) Another explanation for more bleeding in women with STEMI, in our study, could be the high prevalence of PCI during the index hospital care compared with in an NSTEMI-population, as our data shows that the difference in 
bleeding risk between the genders was even more obvious when stratifying by whether PCI was performed or not. In the group that underwent PCI, women had almost three times higher risk of bleeding, and after multivariate adjustment the risk was almost doubled. In contrast, in non-invasively treated patients, women tended to have lower risk of bleeding compared with men. Our findings are also consistent with data from the TRANSLATE-ACS study where women had 32\% higher risk of bleeding during the first year after PCI treated MI, after multivariable adjustment. In that study, where all patients were treated with PCI, no difference between the STEMI and NSTEMI groups was found.(121)

Coronary interventions have been associated with more bleeding complications in women as compared to men. $(122,123)$ In our study we demonstrate that bleeding women were more often invasively treated compared with those who did not bleed, whereas among men the opposite was found. These findings indicate that bleeding in women may be due to the coronary angiography/PCI procedure per se, whereas in men, bleeding may be associated with higher age and comorbidities, possibly withholding them from an invasive strategy. This finding is in line with data from the PLATO trial, showing a more than two-fold risk for PCI-related bleeding in women whereas they actually had lower risk of spontaneous bleeding. (124) Hence our data confirm, and with interaction testing further strengthen, earlier findings regarding higher bleeding incidence in women with STEMI and women treated invasively. Women may have been PCI-treated more often through femoral access than men as radial access is known to be more challenging in female patients because of the small size of the radial artery, radial artery spasm, and puncture failure. (125)

Safe zone arteriotomy when using the femoral artery as access site has been associated with lower risk of bleeding complications, $(126,127)$ this approach might be more challenging in women as they have a shorter common femoral artery compared with men. (128)

\section{Mortality rates}

Cardiovascular disease (CVD) is still the leading cause of death globally. (129) The CAD-related mortality rates in total are higher for men as compared to women, but these differences are slowly diminishing as mortality rates for men decrease. Unfortunately this is not the case in the female part of the population where mortality rates shows an increase in CAD-related mortality. $(130,131)$ When examining mortality after ACS a previous report from the SWEDEHEART registry demonstrated that women had a higher risk of in-hospital mortality compared with men even after adjustment for baseline differences as comorbidities and age.(132) It is also indicated that women have a higher risk of complications, known to be associated with a poor prognosis, as cardiogenic shock, heart failure, vascular complications as well as bleeds. (133) Consistent with previous findings we found a substantially higher mortality among patients with in-hospital bleeding complications, both for women and men. Adverse impact of bleeding has been shown in numerous previous trials, 
but the mechanism for this association is not completely understood. The consequence of bleeding in ACS can be harmful in several ways. Acute bleeding may be life-threatening because of its localisation, for example intracranial bleeds, and severe blood loss can propagate shock. In addition, bleeding leads to anemia and transfusion of blood products, which promote inflammation. (134) Moreover, bleeding may result in cessation of antiplatelet and anticoagulant therapy, which increases the risk of recurrent ischemic events such as stent thrombosis and MI. (135) However, perhaps most important, bleeding patients have been shown to differ from non-bleeding patients in several baseline characteristics with impact on outcome, (see above general discussion) making it important to adjust for these differences when interpreting sex based incidence of bleeding events.

A major and new finding in the present study was the observed sex difference in long-term prognostic impact of in-hospital bleeding. After adjustment, bleeding men had $35 \%$ higher risk of mortality at one year compared with non-bleeders. When adding adjustment for antithrombotic therapy at discharge the difference in risk diminished and was not significant any longer, implying that withdrawal of antiplatelet therapy is one reason for the higher mortality among male bleeders. In contrast, after adjustment there was no association between bleeding and oneyear mortality in women. Sex differences in short-term mortality (30 days) according to bleeding complications have been shown in NSTE ACS patients included in a randomised trial. (136) Our study extends this finding to long-term mortality in a much larger real-life population with both NSTEMI and STEMI, our sub-group analyses point toward that there may be a difference according to type of ACS. The reason for a sex difference in impact of bleeding complications on long-term outcome is not obvious, but there are some possible explanations. To start with, previous trials have shown higher incidence of procedure related bleeding complications in women compared with men (124) and increased risk of bleeding in women treated with angiography and PCI.(137) A study from Germany showed that women had a two-fold increase in access site bleeds compared with men but no significant difference in nonacccess site bleeds.(138) Thus nonaccess site bleeding is a stronger correlate of mortality than access site bleeding. $(124,139-141)$ Data from the TRITON-TIMI 38 study confirms this, showing that women suffers from more access site related bleeds and men have more GI bleeds,(142) which contradicts our results from paper II, where women had more GI bleeds. We cannot differentiate procedural from spontaneous bleedings in the cohort in paper I, although the above findings, with higher bleeding risk in women associated with coronary procedures, support that a larger proportion of the bleeding events in women, compared with men, are procedure related. Continuing, given women's lower baseline hemoglobin value, there may be a greater attention among clinicians for bleeding in women and consequently transfusion treatment. A long-term consequence of transfusions, especially in patients with ACS, is still under debate. (143) Further, cessation of antithrombotic therapies among bleeders would be more dangerous in patients who have undergone stenting. Lower rates of antiplatelet treatment were seen in both male and female bleeders. It is well-known that among ACS patients men undergo PCI (including 
stenting) more often than women, partially due to women's lower incidence of high-risk angiographic features and higher incidence of nonobstructive coronary artery disease in women, (144) why the consequences of lack of antiplatelet treatment may be more important in men. At last, a main explanation could be the observed pronounced difference in risk factors between bleeding and non-bleeding men, indicating that bleeding men are more comorbid and speculatively more frail compared with women.

In both men and women the risk of death appeared to be associated with withdrawal of antithrombotic therapy, as the hazard ratios decreased when adjustment for these therapies was made. This was seen in both the STEMI and NSTEMI groups and is consistent with previous trials, where bleeding patients have been found to be treated less aggressively with antithrombotic medication, possibly leading to stent thrombosis, myocardial infarction and death. (135) Bleeding had a higher impact on long-term mortality for men compared with women in all studied subgroups in paper I.

\section{What is the reason for excess bleeding in women, are we any closer to the solution?}

Excess dosing of antithrombotic and anticoagulant medication may be one explanation. Several studies show that women are more likely to be treated non-invasively, conservatively, (95) even among STEMI patients, (117) they have less high- risk angiographic findings and yet they are given excess doses of multiple antithrombotic agents.(120, 145) (Figure 9)

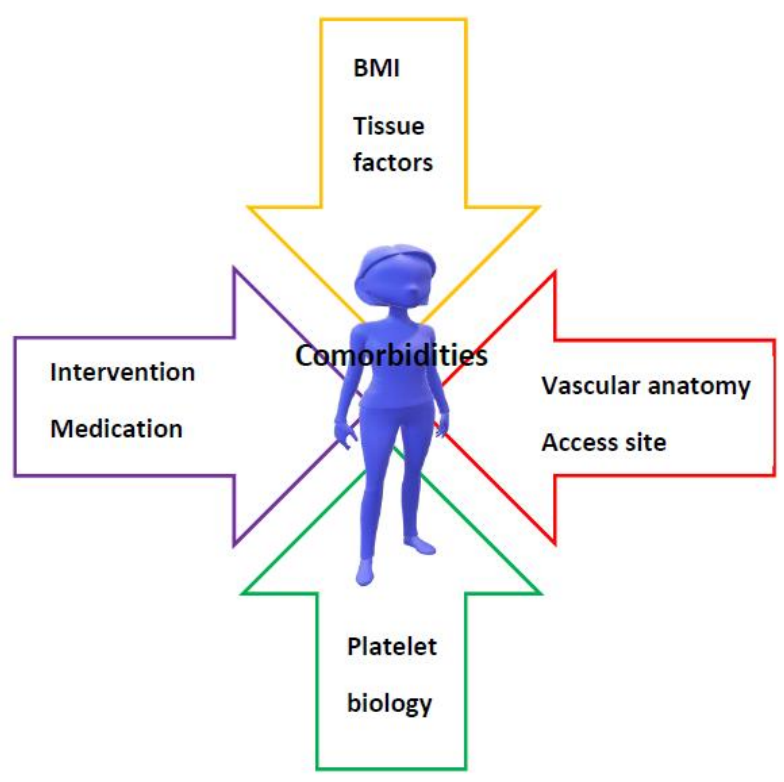

Figure 9. Possible variables influencing increased bleeding risk among women. 
These differences have remained the same for the last decade, women are treated with less interventions and have a higher mortality in-hospital.(146)

In paper III we found that women are more prone to early withdrawal of antithrombotic medication, most often because of bleeds. This is consistent with previous findings from registries where female sex was linked to lower long-term adherence to aspirin, ACE-inhibitors and lipid lowering agents, (147) as well as to antiplatelet agents in patients undergoing PCI. (148)

What further strengthens our findings from medical records with a much higher incidence of bleeding complications compared to regular registries, are data from Wang et al presenting that $43 \%$ of post discharge bleeding events were never brought to medical attention, and thus $28 \%$ of changes in antiplatelet therapies were done without the involvement of a cardiologist. (149)

The reasons for the observed sex based differences in bleeding incidence after MI are thus still incompletely understood. Another hypotheses have been put forward, concerning differences in platelet surface receptor expression, $(93,150)$ linked to excess dosing of antithrombotic drugs, (145)

Previous reports have suggested excess dosing of GP IIb/IIIa-inhibitors in women compared to men, and that this may serve as an explanation to some of the observed differences in bleeding rate. $(145,151)$ Our data in paper IV indicate similar effect of the drug in women and men, with no difference in TRAPinduced platelet aggregation (reflecting the effect of GP IIb/IIIa-inhibition) at several time points. Disparities between our and previous results may depend on the definition of excess dosing. Previous studies defined excess dosing based on given dose, body weight and renal function, while we assessed the effect on TRAP-induced aggregation, an established way to measure the effect of GP IIb/IIIa-inhibitors. We believe that aggregation values may better reflect the individual effect than estimation of dosing based on weight and renal function. Also, differences between our results and previous may be caused by differences in study populations, such as age and comorbidities. We found no significant differences in ADP-stimulated aggregation in paper IV. While previous studies indicated higher ADP-induced aggregation in women among healthy volunteers $(152,153)$ and in one study of clopidogrel treated patients, (154) our results are supported by one study on vascular patients and another study on patients with CAD, treated with DAPT (including clopidogrel and aspirin) post PCI. (155, 156) Therefore, our results, with lack of difference in ADP-stimulated aggregation, are in agreement with previous data from similar patient populations and hence can not support the hypothesis with sex-based diverse platelet reactivity in response to antiplatelet treatment.

In this thesis we have tried to put the focus all the way from cell to clinic to further highlight the disparities between men and women with ACS and bleeding complications.

Further studies are warranted to find the optimal balance between benefit and risk with antiplatelet treatment in both women and men. 


\section{CONCLUSIONS}

Taken together, our data show that there is a remarkably high incidence of bleeding complications after ACS, when treated with dual antiplatelet therapy and even more so if treated with triple antithrombotic therapy in both women and men. The major findings in all four papers are consistent. Women bleed numerously more than men but seem to have more minor or minimal bleeds and seem to withstand bleeding complications better. Female gender is demonstrated to be an independent risk factor for bleeding events but it seems like women have a higher incidence of minor bleeds and the prognostic impact of a bleeding appears to be worse in men.

Several explanatory variables have been presented regarding reasons for women's increased bleeding tendency, for example, diverse platelet function and excess dosing of platelet inhibitors, increased incidence of clinical risk factors as age, renal function and body mass index. Our findings in this thesis can partly support the diverse clinical features between women and men but can not support the hypothesis that women's platelet reactivity differs from that of men and that excess dosing of antiplatelet medication should stand for a substantial part of women's increased bleeding incidence.

In this thesis we present that there is not only a prognostic impact and suffering with a bleeding complication but also a large health care cost for the society. The major knowledge gap today is why women bleed more than men, though several hypotheses have been brought in to the light, the disparities between men and women still remain unclear. 


\section{FOR THE FUTURE}

- Improved strategies to prevent bleeding are warranted for both women and men.

- There is an urgent need for controlled randomised trials to evaluate bleeding complications in patients treated with triple antithrombotic therapy.

- There is a need to understand sex- specific platelet biology.

- The next generation of clinical trials must ensure adequate enrollment of women.

- The care of patients today should be aware of the enhanced risk of bleeding in women.

- Bleeding avoidance strategies should be used in women undergoing PCI. 


\section{APPENDIX}

\section{Bleeding scores Definition}

Thrombolysis in Myocardial Infarction TIMI

Non-CABG related bleeding

- Major

- Any intracranial bleeding (excluding microhemorrhages $<10 \mathrm{~mm}$ evident only on gradient-echo MRI)

- Clinically overt signs of hemorrhage associated with a drop in hemoglobin of $\geq 5 \mathrm{~g} / \mathrm{dL}$

- Fatal bleeding (bleeding that directly results in death within $7 \mathrm{~d}$ )

- Minor

- Clinically overt (including imaging), resulting in hemoglobin drop of 3 to $<5$ $\mathrm{g} / \mathrm{dL}$

- Requiring medical attention

- Any overt sign of hemorrhage that meets one of the following criteria and does not meet criteria for a major or minor bleeding event, as defined above

- Requiring intervention (medical practitioner-guided medical or surgical treatment to stop or treat bleeding, including temporarily or permanently discontinuing or changing the dose of a medication or study drug)

- Leading to or prolonging hospitalization

- Prompting evaluation (leading to an unscheduled visit to a healthcare professional and diagnostic testing, either laboratory or imaging)

- Minimal

- Any overt bleeding event that does not meet the criteria above

- Bleeding in the setting of CABG

- Fatal bleeding (bleeding that directly results in death)

- Perioperative intracranial bleeding

- Reoperation after closure of the sternotomy incision for the purpose of controlling bleeding

- Transfusion of $\geq 5 \mathrm{U}$ PRBCs or whole blood within a 48-h period; cell saver transfusion will not be counted in calculations of blood products.

- Chest tube output $>2 \mathrm{~L}$ within a $24-\mathrm{h}$ period 
Type 0: no bleeding

Type 1: bleeding that is not actionable and does not cause the patient to seek unscheduled performance of studies, hospitalization, or treatment by a healthcare professional; may include episodes leading to self-discontinuation of medical therapy by the patient without consulting a healthcare professional

Type 2: any overt, actionable sign of hemorrhage (eg, more bleeding than would be expected for a clinical circumstance, including bleeding found by imaging alone) that does not fit the criteria for type 3,4 , or 5 but does meet at least one of the following criteria: (1) requiring nonsurgical, medical intervention by a healthcare professional, (2) leading to hospitalization or increased level of care, or (3) prompting evaluation

Type 3

- Type 3a

- Overt bleeding plus hemoglobin drop of 3 to $<5 \mathrm{~g} / \mathrm{dL}^{*}$ (provided hemoglobin drop is related to bleed)

- Any transfusion with overt bleeding

- Type $3 b$

- Overt bleeding plus hemoglobin drop $\geq 5 \mathrm{~g} / \mathrm{dL}^{*}$ (provided hemoglobin drop is related to bleed)

- Cardiac tamponade

- Bleeding requiring surgical intervention for control (excluding dental/nasal/skin/hemorrhoid)

- Bleeding requiring intravenous vasoactive agents

- Type 3c

- Intracranial hemorrhage (does not include microbleeds or hemorrhagic transformation, does include intraspinal)

- Subcategories confirmed by autopsy or imaging or lumbar puncture

- Intraocular bleed compromising vision

Type 4: CABG-related bleeding

- Perioperative intracranial bleeding within $48 \mathrm{~h}$

- Reoperation after closure of sternotomy for the purpose of controlling bleeding

- Transfusion of $\geq 5 \mathrm{U}$ whole blood or packed red blood cells within a 48-h period ${ }^{\dagger}$

- Chest tube output $\geq 2 \mathrm{~L}$ within a $24-\mathrm{h}$ period

Type 5: fatal bleeding

- Type 5a

- Probable fatal bleeding; no autopsy or imaging confirmation but clinically suspicious - Type $5 b$

- Definite fatal bleeding; overt bleeding or autopsy or imaging confirmation 


\section{ACKNOWLEDGEMENTS}

This thesis could, truly, not have been completed without the support and help from so many people. I wish to express my sincere gratitude to everyone who has helped, supported and inspired me on my way to this thesis, in particular to:

Linköping university, for giving me the opportunity to conduct research and write my thesis, without a university, no dissertation.

Eva Swahn, my main supervisor, for believing in me, even when I doubted myself. For your never-ending support and inspiration every day of the year and every time of the day or night. For all the good meals and good talks about research but also about life in general. For being a supervisor that can meet and tutor the PhD student wherever they are and whatever impulsion they have. I could not have wished for a better supervisor and this thesis could truly not have become a reality without you.

Joakim Alfredsson, my co-supervisor, for your expertise on statistics and platelets and your invaluable comments that are well thought through and substantiated by great knowledge. I also would like to thank you for your great supervision and discussions about clinical skills that has helped me on my way to become a doctor.

Sofia Sederholm Lawesson, my co-supervisor and good friend, for bringing light into the world of statistics, SPSS and the writing of syntaxes. Thank you for always having time for me and my research despite a very busy schedule of your own. I really appreciate having you as a collegue, supervisor and friend. Now, when my thesis is finally finished we can start working with all our ideas about new projects........

Magnus Janzon, head of the department of cardiology Linköping university hospital and co-author on paper 3 and 4 . Thank you for all your support, for giving me the opportunity to attend international and national congresses and to take time to do my research. For interesting discussions about research, clinic and leadership. Thank you for creating such a good working climate where clinical and evidence based medicine permeates the everyday work.

All my co-authors, for your invaluable remarks and recommendations 
Ted Cabreira, colleague at the division of ischemia, for your help with journal reviews in paper 2.

Ted Cabreira, Mats Pettersson, Thomas Muhr, Sammy Zwackman and Eva Swahn, Joakim Alfredsson, Sofia Sederholm Lawesson again, my colleagues at the coronary care unit, for support and doing "my" clinical job when I wasn't. Thank you all for making me feel good about going to work even on Mondays.

Maria Eriksson, research nurse, for all your help with the congress posters even at the last minute.

Patients, included in studies that constitute our registers and this thesis.

Kjell Jansson, head of Physiology department Linköping university hospital and colleague, for inspiring me with your clinical skills and wise discussions to start working with cardiology from the beginning.

Sofia Sunnerud, colleague, room mate and friend, for inspiration about the title and front page of my thesis and for all our rewarding discussions about life, love, work and everything in between.

Colleagues and ward staff, at the Department of Cardiology for stimulating collaboration and for contributing to a positive working climate.

My parents, Sven Eric and Anita, for endless support and love throughout life, for principles and for learning me that everything is possible and that I can do whatever I want if I try.

My brother, Tommy and my sister Lena and their families, for support, encouragement and always believing in me. I could not have a better brother or sister. 
Jonas, my beloved husband, friend and also colleague for all your support mentally and hands-on when my computer skills fail...again. Thanks for good ideas and interesting discussions about my papers, this thesis, research and life in general, thanks for being the best dad and husband - we complete each other. Finally thanks for putting up with me and my bad temper through this thesis, better time will come.......

Ellen, my daughter, the love and light of my life. Thanks for keeping on asking when the book is finished and for always reminding me what is really important in life. Keep your curiosity and love for life always. 


\section{REFERENCES}

1. Causes of death 2017, National board of health and welfare, Socialstyrelsen. Swedish national board of health and welfare (Socialstyrelsen); 2018.

2. Mortality GBD, Causes of Death C. Global, regional, and national agesex specific all-cause and cause-specific mortality for 240 causes of death, 1990-2013: a systematic analysis for the Global Burden of Disease Study 2013. Lancet. 2015;385(9963):117-71. Epub 2014/12/23.

3. Libby P, Ridker PM, Hansson GK. Progress and challenges in translating the biology of atherosclerosis. Nature. 2011;473(7347):317-25. Epub 2011/05/20.

4. Tabas I, Garcia-Cardena G, Owens GK. Recent insights into the cellular biology of atherosclerosis. The Journal of cell biology. 2015;209(1):13-22. Epub 2015/04/15.

5. Hansson GK. Inflammation, atherosclerosis, and coronary artery disease. The New England journal of medicine. 2005;352(16):1685-95. Epub 2005/04/22.

6. Davi G, Patrono C. Platelet activation and atherothrombosis. The New England journal of medicine. 2007;357(24):2482-94. Epub 2007/12/14.

7. Mehta SR, Yusuf S, Clopidogrel in Unstable angina to prevent Recurrent Events Study I. The Clopidogrel in Unstable angina to prevent Recurrent Events (CURE) trial programme; rationale, design and baseline characteristics including a meta-analysis of the effects of thienopyridines in vascular disease. European heart journal. 2000;21(24):2033-41. Epub 2000/01/11.

8. Valgimigli M. The ESC DAPT Guidelines 2017. European heart journal. 2018;39(3):187-8. Epub 2018/01/19.

9. Wiviott SD, Braunwald E, McCabe CH, Montalescot G, Ruzyllo W, Gottlieb S, et al. Prasugrel versus clopidogrel in patients with acute coronary syndromes. The New England journal of medicine. 2007;357(20):2001-15. Epub 2007/11/06.

10. Wallentin L, Becker RC, Budaj A, Cannon CP, Emanuelsson H, Held C, et al. Ticagrelor versus clopidogrel in patients with acute coronary syndromes. The New England journal of medicine. 2009;361(11):1045-57. Epub 2009/09/01.

11. Roffi M, Patrono C, Collet JP, Mueller C, Valgimigli M, Andreotti F, et al. 2015 ESC Guidelines for the management of acute coronary syndromes in patients presenting without persistent ST-segment elevation: Task Force for the Management of Acute Coronary Syndromes in Patients Presenting without Persistent ST-Segment Elevation of the European Society of Cardiology (ESC). European heart journal. 2016;37(3):267-315. Epub 2015/09/01.

12. Ibanez B, James S, Agewall S, Antunes MJ, Bucciarelli-Ducci C, Bueno $\mathrm{H}$, et al. 2017 ESC Guidelines for the management of acute myocardial infarction in patients presenting with ST-segment elevation. Revista espanola de cardiologia. 2017;70(12):1082. Epub 2017/12/05.

13. Sutton NR, Seth M, Ruwende C, Gurm HS. Outcomes of Patients With Atrial Fibrillation Undergoing Percutaneous Coronary Intervention. Journal of the American College of Cardiology. 2016;68(9):895-904. Epub 2016/08/27. 
14. Investigators AWGotA, Connolly S, Pogue J, Hart R, Pfeffer M, Hohnloser S, et al. Clopidogrel plus aspirin versus oral anticoagulation for atrial fibrillation in the Atrial fibrillation Clopidogrel Trial with Irbesartan for prevention of Vascular Events (ACTIVE W): a randomised controlled trial. Lancet. 2006;367(9526):1903-12. Epub 2006/06/13.

15. Hess CN, Peterson ED, Peng SA, de Lemos JA, Fosbol EL, Thomas L, et al. Use and Outcomes of Triple Therapy Among Older Patients With Acute Myocardial Infarction and Atrial Fibrillation. Journal of the American College of Cardiology. 2015;66(6):616-27. Epub 2015/08/o8.

16. Eikelboom JW, Mehta SR, Anand SS, Xie C, Fox KA, Yusuf S. Adverse impact of bleeding on prognosis in patients with acute coronary syndromes. Circulation. 2006;114(8):774-82. Epub 2006/08/16.

17. Rao SV, O'Grady K, Pieper KS, Granger CB, Newby LK, Van de Werf F, et al. Impact of bleeding severity on clinical outcomes among patients with acute coronary syndromes. The American journal of cardiology. 2005;96(9):1200-6. Epub 2005/10/29.

18. Manoukian SV. Predictors and impact of bleeding complications in percutaneous coronary intervention, acute coronary syndromes, and STsegment elevation myocardial infarction. The American journal of cardiology. 2009;104(5 Suppl):9C-15C. Epub 2009/08/27.

19. Hochman JS, Tamis-Holland JE. Acute coronary syndromes: does sex matter? Jama. 2002;288(24):3161-4. Epub 2002/12/27.

20. Champney KP, Frederick PD, Bueno H, Parashar S, Foody J, Merz CN, et al. The joint contribution of sex, age and type of myocardial infarction on hospital mortality following acute myocardial infarction. Heart. 2009;95(11):895-9. Epub 2009/01/17.

21. Hansen ML, Sorensen R, Clausen MT, Fog-Petersen ML, Raunso J, Gadsboll N, et al. Risk of bleeding with single, dual, or triple therapy with warfarin, aspirin, and clopidogrel in patients with atrial fibrillation. Archives of internal medicine. 2010;170(16):1433-41. Epub 2010/09/15.

22. Lopes RD, Subherwal S, Holmes DN, Thomas L, Wang TY, Rao SV, et al. The association of in-hospital major bleeding with short-, intermediate, and long-term mortality among older patients with non-ST-segment elevation myocardial infarction. European heart journal. 2012;33(16):2044-53. Epub 2012/03/o8.

23. Manoukian SV, Feit F, Mehran R, Voeltz MD, Ebrahimi R, Hamon M, et al. Impact of major bleeding on 30-day mortality and clinical outcomes in patients with acute coronary syndromes: an analysis from the ACUITY Trial. Journal of the American College of Cardiology. 2007;49(12):1362-8. Epub 2007/03/31.

24. Reinecke H, Trey T, Wellmann J, Heidrich J, Fobker M, Wichter T, et al. Haemoglobin-related mortality in patients undergoing percutaneous coronary interventions. European heart journal. 2003;24(23):2142-50. Epub 2003/12/04.

25. Hill SR, Carless PA, Henry DA, Carson JL, Hebert PC, McClelland DB, et al. Transfusion thresholds and other strategies for guiding allogeneic red blood cell transfusion. The Cochrane database of systematic reviews. 2002(2):CDo02042. Epub 2002/06/22.

26. Aronson D, Dann EJ, Bonstein L, Blich M, Kapeliovich M, Beyar R, et al. Impact of red blood cell transfusion on clinical outcomes in patients with acute myocardial infarction. The American journal of cardiology. 2008;102(2):115-9. Epub 2008/07/08.

27. Carson JL, Carless PA, Hebert PC. Outcomes using lower vs higher hemoglobin thresholds for red blood cell transfusion. Jama. 2013;309(1):83-4. Epub 2013/01/03. 
28. Salisbury AC, Reid KJ, Marso SP, Amin AP, Alexander KP, Wang TY, et al. Blood transfusion during acute myocardial infarction: association with mortality and variability across hospitals. Journal of the American College of Cardiology. 2014;64(8):811-9. Epub 2014/08/26.

29. Steinhubl SR, Kastrati A, Berger PB. Variation in the definitions of bleeding in clinical trials of patients with acute coronary syndromes and undergoing percutaneous coronary interventions and its impact on the apparent safety of antithrombotic drugs. American heart journal. 2007;154(1):3-11. Epub 2007/06/23.

30. Schulman S, Kearon C, Subcommittee on Control of Anticoagulation of the S, Standardization Committee of the International Society on T, Haemostasis. Definition of major bleeding in clinical investigations of antihemostatic medicinal products in non-surgical patients. Journal of thrombosis and haemostasis : JTH. 2005;3(4):692-4. Epub 2005/04/22.

31. Cohen M, Alexander KP, Rao SV. Bleeding after antithrombotic therapy in patients with acute ischemic heart disease: is it the drugs or how we use them? Journal of thrombosis and thrombolysis. 2008;26(3):175-82. Epub 2007/12/18.

32. Chesebro JH, Knatterud G, Roberts R, Borer J, Cohen LS, Dalen J, et al. Thrombolysis in Myocardial Infarction (TIMI) Trial, Phase I: A comparison between intravenous tissue plasminogen activator and intravenous streptokinase. Clinical findings through hospital discharge. Circulation. 1987;76(1):142-54. Epub 1987/07/01.

33. Bovill EG, Terrin ML, Stump DC, Berke AD, Frederick M, Collen D, et al. Hemorrhagic events during therapy with recombinant tissue-type plasminogen activator, heparin, and aspirin for acute myocardial infarction. Results of the Thrombolysis in Myocardial Infarction (TIMI), Phase II Trial. Annals of internal medicine. 1991;115(4):256-65. Epub 1991/o8/15.

34. Mega JL, Braunwald E, Mohanavelu S, Burton P, Poulter R, Misselwitz $\mathrm{F}$, et al. Rivaroxaban versus placebo in patients with acute coronary syndromes (ATLAS ACS-TIMI 46): a randomised, double-blind, phase II trial. Lancet. 2009;374(9683):29-38. Epub 2009/06/23.

35. Sabatine MS, Antman EM, Widimsky P, Ebrahim IO, Kiss RG, Saaiman $\mathrm{A}$, et al. Otamixaban for the treatment of patients with non-ST-elevation acute coronary syndromes (SEPIA-ACS1 TIMI 42): a randomised, doubleblind, active-controlled, phase 2 trial. Lancet. 2009;374(9692):787-95. Epub 2009/09/01.

36. Mehran R, Rao SV, Bhatt DL, Gibson CM, Caixeta A, Eikelboom J, et al. Standardized bleeding definitions for cardiovascular clinical trials: a consensus report from the Bleeding Academic Research Consortium. Circulation. 2011;123(23):2736-47. Epub 2011/06/15.

37. Michelson A. Platelets. Third edition ed: Elsevier Inc; 2013.

38. Jenne CN, Urrutia R, Kubes P. Platelets: bridging hemostasis, inflammation, and immunity. International journal of laboratory hematology. 2013;35(3):254-61. Epub 2013/04/18.

39. Mancuso ME, Santagostino E. Platelets: much more than bricks in a breached wall. British journal of haematology. 2017;178(2):209-19. Epub 2017/04/19.

40. Clemetson KJ. Platelets and primary haemostasis. Thrombosis research. 2012;129(3):220-4. Epub 2011/12/20.

41. Ruggeri ZM, Mendolicchio GL. Adhesion mechanisms in platelet function. Circulation research. 2007;100(12):1673-85. Epub 2007/06/23. 
42. Yip J, Shen Y, Berndt MC, Andrews RK. Primary platelet adhesion receptors. IUBMB life. 2005;57(2):103-8. Epub 2005/07/23.

43. George JN. Platelets. Lancet. 2000;355(9214):1531-9. Epub 2000/05/09.

44. Fass.se. 2018-11-14.

45. Peters RJ, Mehta SR, Fox KA, Zhao F, Lewis BS, Kopecky SL, et al. Effects of aspirin dose when used alone or in combination with clopidogrel in patients with acute coronary syndromes: observations from the Clopidogrel in Unstable angina to prevent Recurrent Events (CURE) study. Circulation. 2003;108(14):1682-7. Epub 2003/09/25.

46. Task Force M, Montalescot G, Sechtem U, Achenbach S, Andreotti F, Arden C, et al. 2013 ESC guidelines on the management of stable coronary artery disease: the Task Force on the management of stable coronary artery disease of the European Society of Cardiology. European heart journal. 2013;34(38):2949-3003. Epub 2013/09/03.

47. Ibanez B, James S, Agewall S, Antunes MJ, Bucciarelli-Ducci C, Bueno $\mathrm{H}$, et al. 2017 ESC Guidelines for the management of acute myocardial infarction in patients presenting with ST-segment elevation: The Task Force for the management of acute myocardial infarction in patients presenting with ST-segment elevation of the European Society of Cardiology (ESC). European heart journal. 2018;39(2):119-77. Epub 2017/09/10.

48. Risk of myocardial infarction and death during treatment with low dose aspirin and intravenous heparin in men with unstable coronary artery disease. The RISC Group. Lancet. 1990;336(8719):827-30. Epub 1990/10/o6.

49. Lewis HD, Jr., Davis JW, Archibald DG, Steinke WE, Smitherman TC, Doherty JE, 3rd, et al. Protective effects of aspirin against acute myocardial infarction and death in men with unstable angina. Results of a Veterans Administration Cooperative Study. The New England journal of medicine. 1983;309(7):396-403. Epub 1983/08/18.

50. Cairns JA, Gent M, Singer J, Finnie KJ, Froggatt GM, Holder DA, et al. Aspirin, sulfinpyrazone, or both in unstable angina. Results of a Canadian multicenter trial. The New England journal of medicine. 1985;313(22):1369-75. Epub 1985/11/28.

51. Antithrombotic Trialists C, Baigent C, Blackwell L, Collins R, Emberson J, Godwin J, et al. Aspirin in the primary and secondary prevention of vascular disease: collaborative meta-analysis of individual participant data from randomised trials. Lancet. 2009;373(9678):1849-60. Epub 2009/06/02.

52. Randomised trial of intravenous streptokinase, oral aspirin, both, or neither among 17,187 cases of suspected acute myocardial infarction: ISIS2. ISIS-2 (Second International Study of Infarct Survival) Collaborative Group. Lancet. 1988;2(8607):349-60. Epub 1988/08/13.

53. Qayyum R, Becker DM, Yanek LR, Moy TF, Becker LC, Faraday N, et al. Platelet inhibition by aspirin 81 and $325 \mathrm{mg}$ /day in men versus women without clinically apparent cardiovascular disease. The American journal of cardiology. 2008;101(9):1359-63. Epub 2008/04/26.

54. Becker DM, Segal J, Vaidya D, Yanek LR, Herrera-Galeano JE, Bray $\mathrm{PF}$, et al. Sex differences in platelet reactivity and response to low-dose aspirin therapy. Jama. 2006;295(12):1420-7. Epub 2006/03/23.

55. Sam K. Studies on platelet function and microvesicles in acute coronary syndrome. Stockholm, Sweden: Karolinska institutet; 2018. 
56. Patrono C, Andreotti F, Arnesen H, Badimon L, Baigent C, Collet JP, et al. Antiplatelet agents for the treatment and prevention of atherothrombosis. European heart journal. 2011;32(23):2922-32. Epub 2011/10/25.

57. Eikelboom JW, Hirsh J, Spencer FA, Baglin TP, Weitz JI. Antiplatelet drugs: Antithrombotic Therapy and Prevention of Thrombosis, 9th ed: American College of Chest Physicians Evidence-Based Clinical Practice Guidelines. Chest. 2012;141(2 Suppl):e89S-e119S. Epub 2012/02/15.

58. Mega JL, Close SL, Wiviott SD, Shen L, Hockett RD, Brandt JT, et al. Cytochrome p-450 polymorphisms and response to clopidogrel. The New England journal of medicine. 2009;360(4):354-62. Epub 2008/12/25.

59. Matetzky S, Shenkman B, Guetta V, Shechter M, Beinart R, Goldenberg $\mathrm{I}$, et al. Clopidogrel resistance is associated with increased risk of recurrent atherothrombotic events in patients with acute myocardial infarction. Circulation. 2004;109(25):3171-5. Epub 2004/06/09.

6o. Cuisset T, Frere C, Quilici J, Barbou F, Morange PE, Hovasse T, et al. High post-treatment platelet reactivity identified low-responders to dual antiplatelet therapy at increased risk of recurrent cardiovascular events after stenting for acute coronary syndrome. Journal of thrombosis and haemostasis : JTH. 2006;4(3):542-9. Epub 2005/12/24.

61. Hochholzer W, Trenk D, Bestehorn HP, Fischer B, Valina CM, Ferenc $\mathrm{M}$, et al. Impact of the degree of peri-interventional platelet inhibition after loading with clopidogrel on early clinical outcome of elective coronary stent placement. Journal of the American College of Cardiology. 2006;48(9):1742-50. Epub 2006/11/07.

62. Thomas MR, Storey RF. Clinical significance of residual platelet reactivity in patients treated with platelet $\mathrm{P} 2 \mathrm{Y} 12$ inhibitors. Vascular pharmacology. 2016;84:25-7. Epub 2016/06/09.

63. Price MJ. Bedside evaluation of thienopyridine antiplatelet therapy. Circulation. 2009;119(19):2625-32. Epub 2009/05/20.

64. Bonello L, Tantry US, Marcucci R, Blindt R, Angiolillo DJ, Becker R, et al. Consensus and future directions on the definition of high on-treatment platelet reactivity to adenosine diphosphate. Journal of the American College of Cardiology. 2010;56(12):919-33. Epub 2010/09/11.

65. Sibbing D, Steinhubl SR, Schulz S, Schomig A, Kastrati A. Platelet aggregation and its association with stent thrombosis and bleeding in clopidogrel-treated patients: initial evidence of a therapeutic window. Journal of the American College of Cardiology. 2010;56(4):317-8. Epub 2010/07/17.

66. Shuldiner AR, O'Connell JR, Bliden KP, Gandhi A, Ryan K, Horenstein $\mathrm{RB}$, et al. Association of cytochrome $\mathrm{P} 450$ 2C19 genotype with the antiplatelet effect and clinical efficacy of clopidogrel therapy. Jama. 2009;302(8):849-57. Epub 2009/08/27.

67. Price MJ, Murray SS, Angiolillo DJ, Lillie E, Smith EN, Tisch RL, et al. Influence of genetic polymorphisms on the effect of high- and standarddose clopidogrel after percutaneous coronary intervention: the GIFT (Genotype Information and Functional Testing) study. Journal of the American College of Cardiology. 2012;59(22):1928-37. Epub 2012/05/26.

68. Kassimis G, Davlouros P, Xanthopoulou I, Stavrou EF, Athanassiadou A, Alexopoulos D. CYP2C19*2 and other genetic variants affecting platelet response to clopidogrel in patients undergoing percutaneous coronary intervention. Thrombosis research. 2012;129(4):441-6. Epub 2011/08/13. 69. Park JJ, Park KW, Kang J, Jeon KH, Kang SH, Ahn HS, et al. Genetic determinants of clopidogrel responsiveness in Koreans treated with drug- 
eluting stents. International journal of cardiology. 2013;163(1):79-86. Epub 2012/12/25.

70. Bouman HJ, Harmsze AM, van Werkum JW, Breet NJ, Bergmeijer TO, Ten Cate H, et al. Variability in on-treatment platelet reactivity explained by $\mathrm{CYP}_{2} \mathrm{C} 19 * 2$ genotype is modest in clopidogrel pretreated patients undergoing coronary stenting. Heart (British Cardiac Society). 2011;97(15):1239-44. Epub 2011/06/02.

71. Yusuf S, Zhao F, Mehta SR, Chrolavicius S, Tognoni G, Fox KK, et al. Effects of clopidogrel in addition to aspirin in patients with acute coronary syndromes without ST-segment elevation. The New England journal of medicine. 2001;345(7):494-502. Epub 2001/08/25.

72. Sabatine MS, Cannon CP, Gibson CM, Lopez-Sendon JL, Montalescot G, Theroux P, et al. Addition of clopidogrel to aspirin and fibrinolytic therapy for myocardial infarction with ST-segment elevation. The New England journal of medicine. 2005;352(12):1179-89. Epub 2005/03/11.

73. Berger JS, Bhatt DL, Cannon CP, Chen Z, Jiang L, Jones JB, et al. The relative efficacy and safety of clopidogrel in women and men a sex-specific collaborative meta-analysis. Journal of the American College of Cardiology. 2009;54(21):1935-45. Epub 2009/11/17.

74. Brandt JT, Close SL, Iturria SJ, Payne CD, Farid NA, Ernest CS, 2nd, et al. Common polymorphisms of CYP2C19 and CYP2C9 affect the pharmacokinetic and pharmacodynamic response to clopidogrel but not prasugrel. Journal of thrombosis and haemostasis : JTH. 2007;5(12):242936. Epub 2007/09/29.

75. Fass.se 2018-11-15. 2018.

76. Wiviott SD, Desai N, Murphy SA, Musumeci G, Ragosta M, Antman EM, et al. Efficacy and safety of intensive antiplatelet therapy with prasugrel from TRITON-TIMI 38 in a core clinical cohort defined by worldwide regulatory agencies. The American journal of cardiology. 2011;108(7):905-11. Epub 2011/08/06.

77. Cannon CP, Harrington RA, James S, Ardissino D, Becker RC, Emanuelsson $\mathrm{H}$, et al. Comparison of ticagrelor with clopidogrel in patients with a planned invasive strategy for acute coronary syndromes (PLATO): a randomised double-blind study. Lancet. 2010;375(9711):283-93. Epub 2010/01/19.

78. Topol EJ, Byzova TV, Plow EF. Platelet GPIIb-IIIa blockers. Lancet. 1999;353(9148):227-31. Epub 1999/01/29.

79. De Luca G, Navarese E, Marino P. Risk profile and benefits from Gp IIb-IIIa inhibitors among patients with ST-segment elevation myocardial infarction treated with primary angioplasty: a meta-regression analysis of randomized trials. European heart journal. 2009;30(22):2705-13. Epub 2009/10/31.

8o. Ellis SG, Tendera M, de Belder MA, van Boven AJ, Widimsky P, Janssens L, et al. Facilitated PCI in patients with ST-elevation myocardial infarction. The New England journal of medicine. 2008;358(21):2205-17. Epub 2008/05/24.

81. Atherton A, Begent N, Blackwell GJ, Bakhle YS. The platelet aggregometer and beyond: Gustav Born at the Royal College of Surgeons. Platelets. 2018:1-4. Epub 2018/09/12.

82. Cattaneo M, Hayward CP, Moffat KA, Pugliano MT, Liu Y, Michelson $\mathrm{AD}$. Results of a worldwide survey on the assessment of platelet function by light transmission aggregometry: a report from the platelet physiology subcommittee of the SSC of the ISTH. Journal of thrombosis and haemostasis : JTH. 2009;7(6):1029. Epub 2009/05/09. 
83. Toth O, Calatzis A, Penz S, Losonczy H, Siess W. Multiple electrode aggregometry: a new device to measure platelet aggregation in whole blood. Thrombosis and haemostasis. 2006;96(6):781-8. Epub 2006/12/02.

84. Causes of death 2017. Swedish board of national health and welfare (Socialstyrelsen); 2018.

85. Lawesson SS, Stenestrand U, Lagerqvist B, Wallentin L, Swahn E. Gender perspective on risk factors, coronary lesions and long-term outcome in young patients with ST-elevation myocardial infarction. Heart. 2010;96(6):453-9. Epub 2010/03/20.

86. Udell JA, Fonarow GC, Maddox TM, Cannon CP, Frank Peacock W, Laskey WK, et al. Sustained sex-based treatment differences in acute coronary syndrome care: Insights from the American Heart Association Get With The Guidelines Coronary Artery Disease Registry. Clinical cardiology. 2018;41(6):758-68. Epub 2018/03/10.

87. Oldgren J, Wernroth L, Stenestrand U, Riks-Hia registry S. Fibrinolytic therapy and bleeding complications: risk predictors from RIKS-HIA. Heart (British Cardiac Society). 2010;96(18):1451-7. Epub 2010/07/27.

88. Mehran R, Pocock SJ, Nikolsky E, Clayton T, Dangas GD, Kirtane AJ, et al. A risk score to predict bleeding in patients with acute coronary syndromes. Journal of the American College of Cardiology. 2010;55(23):2556-66. Epub 2010/06/02.

89. Moscucci M, Fox KA, Cannon CP, Klein W, Lopez-Sendon J, Montalescot G, et al. Predictors of major bleeding in acute coronary syndromes: the Global Registry of Acute Coronary Events (GRACE). European heart journal. 2003;24(20):1815-23. Epub 2003/10/18.

90. Johnson M, Ramey E, Ramwell PW. Sex and age differences in human platelet aggregation. Nature. 1975;253(5490):355-7. Epub 1975/01/31.

91. Segal JB, Moliterno AR. Platelet counts differ by sex, ethnicity, and age in the United States. Annals of epidemiology. 2006;16(2):123-30. Epub 2005/10/26.

92. Giustino G, Kirtane AJ, Genereux P, Baber U, Witzenbichler B, Neumann FJ, et al. Relation Between Platelet Count and Platelet Reactivity to Thrombotic and Bleeding Risk: From the Assessment of Dual Antiplatelet Therapy With Drug-Eluting Stents Study. The American journal of cardiology. 2016;117(11):1703-13. Epub 2016/04/14.

93. Faraday N, Goldschmidt-Clermont PJ, Bray PF. Gender differences in platelet GPIIb-IIIa activation. Thrombosis and haemostasis. 1997;77(4):748-54. Epub 1997/04/01.

94. Holm A, Sederholm Lawesson S, Swahn E, Alfredsson J. Editor's Choice- Gender difference in prognostic impact of in-hospital bleeding after myocardial infarction - data from the SWEDEHEART registry. European heart journal Acute cardiovascular care. 2016;5(6):463-72. Epub 2015/10/10.

95. Gutierrez-Chico JL, Mehilli J. Gender differences in cardiovascular therapy: focus on antithrombotic therapy and percutaneous coronary intervention. Drugs. 2013;73(17):1921-33. Epub 2013/10/25.

96. Regitz-Zagrosek V, Oertelt-Prigione S, Seeland U, Hetzer R. Sex and gender differences in myocardial hypertrophy and heart failure. Circulation journal : official journal of the Japanese Circulation Society. 2010;74(7):1265-73. Epub 2010/06/19.

97. Bugiardini R. Women, 'non-specific' chest pain, and normal or nearnormal coronary angiograms are not synonymous with favourable outcome. European heart journal. 2006;27(12):1387-9. Epub 2006/05/25. 
98. Johnson BD, Shaw LJ, Buchthal SD, Bairey Merz CN, Kim HW, Scott $\mathrm{KN}$, et al. Prognosis in women with myocardial ischemia in the absence of obstructive coronary disease: results from the National Institutes of Health-National Heart, Lung, and Blood Institute-Sponsored Women's Ischemia Syndrome Evaluation (WISE). Circulation. 2004;109(24):29939. Epub 2004/06/16.

99. Arbustini E, Dal Bello B, Morbini P, Burke AP, Bocciarelli M, Specchia $\mathrm{G}$, et al. Plaque erosion is a major substrate for coronary thrombosis in acute myocardial infarction. Heart. 1999;82(3):269-72. Epub 1999/o8/24. 100. Lindmark E, Wallentin L, Siegbahn A. Blood cell activation, coagulation, and inflammation in men and women with coronary artery disease. Thrombosis research. 2001;103(3):249-59. Epub 2001/10/24.

101.Nikolic E, Janzon M, Hauch O, Wallentin L, Henriksson M, Group PHES. Cost-effectiveness of treating acute coronary syndrome patients with ticagrelor for 12 months: results from the PLATO study. European heart journal. 2013;34(3):220-8. Epub 2012/06/22.

102. Lips HM. Sex \& Gender, An introduction. sixth edition ed. Illinois: Waveland Press Inc; 2017.

103. Jernberg T, Attebring MF, Hambraeus K, Ivert T, James S, Jeppsson A, et al. The Swedish Web-system for enhancement and development of evidence-based care in heart disease evaluated according to recommended therapies (SWEDEHEART). Heart. 2010;96(20):1617-21. Epub 2010/08/31.

104. Thygesen K, Alpert JS, White HD, Joint ESCAAHAWHFTFftRoMI, Jaffe AS, Apple FS, et al. Universal definition of myocardial infarction. Circulation. 2007;116(22):2634-53. Epub 2007/10/24.

105. Drummond M. Methods for the economic evaluation of health care programmes. Fourth edition ed. Oxford: Oxford press; 2015.

106. Alfredsson J, Lindahl TL, Gustafsson KM, Janzon M, Jonasson $\mathrm{L}$, Logander E, et al. Large early variation of residual platelet reactivity in Acute Coronary Syndrome patients treated with clopidogrel: results from Assessing Platelet Activity in Coronary Heart Disease (APACHE). Thrombosis research. 2015;136(2):335-40. Epub 2015/06/03.

107. Ahmed B, Dauerman HL. Women, bleeding, and coronary intervention. Circulation. 2013;127(5):641-9. Epub 2013/02/o6.

108. Melloni C, Berger JS, Wang TY, Gunes F, Stebbins A, Pieper KS, et al. Representation of women in randomized clinical trials of cardiovascular disease prevention. Circulation Cardiovascular quality and outcomes. 2010;3(2):135-42. Epub 2010/02/18.

109. Capodanno D, Angiolillo DJ. Impact of race and gender on antithrombotic therapy. Thrombosis and haemostasis. 2010;104(3):47184. Epub 2010/07/29.

110.Blomkalns AL, Chen AY, Hochman JS, Peterson ED, Trynosky K, Diercks DB, et al. Gender disparities in the diagnosis and treatment of nonST-segment elevation acute coronary syndromes: large-scale observations from the CRUSADE (Can Rapid Risk Stratification of Unstable Angina Patients Suppress Adverse Outcomes With Early Implementation of the American College of Cardiology/American Heart Association Guidelines) National Quality Improvement Initiative. Journal of the American College of Cardiology. 2005;45(6):832-7. Epub 2005/03/16.

111. Diercks DB, Owen KP, Kontos MC, Blomkalns A, Chen AY, Miller C, et al. Gender differences in time to presentation for myocardial infarction before and after a national women's cardiovascular awareness campaign: a temporal analysis from the Can Rapid Risk Stratification of Unstable 
Angina Patients Suppress ADverse Outcomes with Early Implementation (CRUSADE) and the National Cardiovascular Data Registry Acute Coronary Treatment and Intervention Outcomes Network-Get with the Guidelines (NCDR ACTION Registry-GWTG). American heart journal. 2010;160(1):80-7 e3. Epub 2010/07/06.

112. Statistics on myocardial infarction. In: (Socialstyrelsen) Nbohaw, editor. 2016.

113. Husted S, James SK, Bach RG, Becker RC, Budaj A, Heras M, et al. The efficacy of ticagrelor is maintained in women with acute coronary syndromes participating in the prospective, randomized, PLATelet inhibition and patient Outcomes (PLATO) trial. European heart journal. 2014;35(23):1541-50. Epub 2014/04/01.

114. Wang WT, James SK, Wang TY. A review of sex-specific benefits and risks of antithrombotic therapy in acute coronary syndrome. European heart journal. 2017;38(3):165-71. Epub 2017/02/o6.

115. Mehta RH, Stebbins AS, Lopes RD, Califf RM, Pieper KS, Armstrong $\mathrm{PW}$, et al. Comparison of incidence of bleeding and mortality of men versus women with ST-elevation myocardial infarction treated with fibrinolysis. The American journal of cardiology. 2012;109(3):320-6. Epub 2011/11/15. 116. Chacko M, Lincoff AM, Wolski KE, Cohen DJ, Bittl JA, Lansky AJ, et al. Ischemic and bleeding outcomes in women treated with bivalirudin during percutaneous coronary intervention: a subgroup analysis of the Randomized Evaluation in PCI Linking Angiomax to Reduced Clinical Events (REPLACE)-2 trial. American heart journal. 2006;151(5):1032 e1-7. Epub 2006/04/29.

117. Yu J, Mehran R, Grinfeld L, Xu K, Nikolsky E, Brodie BR, et al. Sexbased differences in bleeding and long term adverse events after percutaneous coronary intervention for acute myocardial infarction: three year results from the HORIZONS-AMI trial. Catheterization and cardiovascular interventions : official journal of the Society for Cardiac Angiography \& Interventions. 2015;85(3):359-68. Epub 2014/o8/15.

118. Reynolds HR, Farkouh ME, Lincoff AM, Hsu A, Swahn E, Sadowski ZP, et al. Impact of female sex on death and bleeding after fibrinolytic treatment of myocardial infarction in GUSTO V. Archives of internal medicine. 2007;167(19):2054-60. Epub 2007/10/24.

119. Boersma E, Harrington RA, Moliterno DJ, White H, Theroux P, Van de Werf F, et al. Platelet glycoprotein IIb/IIIa inhibitors in acute coronary syndromes: a meta-analysis of all major randomised clinical trials. Lancet. 2002;359(9302):189-98. Epub 2002/01/29.

120. Alexander KP, Chen AY, Newby LK, Schwartz JB, Redberg RF, Hochman JS, et al. Sex differences in major bleeding with glycoprotein IIb/IIIa inhibitors: results from the CRUSADE (Can Rapid risk stratification of Unstable angina patients Suppress ADverse outcomes with Early implementation of the ACC/AHA guidelines) initiative. Circulation. 2006;114(13):1380-7. Epub 2006/09/20.

121. Hess CN, McCoy LA, Duggirala HJ, Tavris DR, O'Callaghan K, Douglas PS, et al. Sex-based differences in outcomes after percutaneous coronary intervention for acute myocardial infarction: a report from TRANSLATEACS. Journal of the American Heart Association. 2014;3(1): e000523. Epub 2014/02/11.

122. Lansky AJ, Pietras C, Costa RA, Tsuchiya Y, Brodie BR, Cox DA, et al. Gender differences in outcomes after primary angioplasty versus primary stenting with and without abciximab for acute myocardial infarction: results of the Controlled Abciximab and Device Investigation to 
Lower Late Angioplasty Complications (CADILLAC) trial. Circulation. 2005;111(13):1611-8. Epub 2005/04/07.

123. Ahmed B, Piper WD, Malenka D, VerLee P, Robb J, Ryan T, et al. Significantly improved vascular complications among women undergoing percutaneous coronary intervention: a report from the Northern New England Percutaneous Coronary Intervention Registry. Circulation Cardiovascular interventions. 2009;2(5):423-9. Epub 2009/12/25.

124. Becker RC, Bassand JP, Budaj A, Wojdyla DM, James SK, Cornel $\mathrm{JH}$, et al. Bleeding complications with the $\mathrm{P} 2 \mathrm{Y}_{12}$ receptor antagonists clopidogrel and ticagrelor in the PLATelet inhibition and patient Outcomes (PLATO) trial. European heart journal. 2011;32(23):2933-44. Epub 2011/11/18.

125. Tizon-Marcos H, Bertrand OF, Rodes-Cabau J, Larose E, Gaudreault V, Bagur R, et al. Impact of female gender and transradial coronary stenting with maximal antiplatelet therapy on bleeding and ischemic outcomes. American heart journal. 2009;157(4):740-5. Epub 2009/04/01.

126. Fitts J, Ver Lee P, Hofmaster P, Malenka D, Northern New England Cardiovascular Study G. Fluoroscopy-guided femoral artery puncture reduces the risk of PCI-related vascular complications. Journal of interventional cardiology. 2008;21(3):273-8. Epub 2008/03/18.

127. Stone GW, Witzenbichler B, Guagliumi G, Peruga JZ, Brodie BR, Dudek D, et al. Bivalirudin during primary PCI in acute myocardial infarction. The New England journal of medicine. 2008;358(21):2218-30. Epub 2008/05/24.

128. Sandgren T, Sonesson B, Ahlgren R, Lanne T. The diameter of the common femoral artery in healthy human: influence of sex, age, and body size. Journal of vascular surgery. 1999;29(3):503-10. Epub 1999/03/09.

129. World health organisation. The global burden of disease. [database on the Internet]. 2015.

130. Rosamond W, Flegal K, Furie K, Go A, Greenlund K, Haase N, et al. Heart disease and stroke statistics--2008 update: a report from the American Heart Association Statistics Committee and Stroke Statistics Subcommittee. Circulation. 2008;117(4):e25-146. Epub 2007/12/19.

131. Wenger NK. Prevention of cardiovascular disease in women: highlights for the clinician of the 2011 American Heart Association Guidelines. Advances in chronic kidney disease. 2013;20(5):419-22. Epub 2013/08/28.

132. Lawesson SS, Alfredsson J, Fredrikson M, Swahn E. A gender perspective on short- and long term mortality in ST-elevation myocardial infarction--a report from the SWEDEHEART register. International journal of cardiology. 2013;168(2):1041-7. Epub 2012/11/22.

133. Redfors B, Angeras O, Ramunddal T, Petursson P, Haraldsson I, Dworeck C, et al. Trends in Gender Differences in Cardiac Care and Outcome After Acute Myocardial Infarction in Western Sweden: A Report From the Swedish Web System for Enhancement of Evidence-Based Care in Heart Disease Evaluated According to Recommended Therapies (SWEDEHEART). Journal of the American Heart Association. 2015;4(7). Epub 2015/07/16.

134. Willis P, Voeltz MD. Anemia, hemorrhage, and transfusion in percutaneous coronary intervention, acute coronary syndromes, and STsegment elevation myocardial infarction. The American journal of cardiology. 2009;104(5 Suppl):34C-8C. Epub 2009/08/27. 
135 .

Chan MY, Sun JL, Wang TY, Lopes RD, Jolicoeur ME, Pieper KS, et al. Patterns of discharge antiplatelet therapy and late outcomes among 8,582 patients with bleeding during acute coronary syndrome: a pooled analysis from PURSUIT, PARAGON-A, PARAGON-B, and SYNERGY. American heart journal. 2010;160(6):1056-64, 64 e2. Epub 2010/12/15.

136. Kaul P, Tanguay JF, Newby LK, Hochman JS, Westerhout CM, Califf RM, et al. Association between bleeding and mortality among women and men with high-risk acute coronary syndromes: insights from the Early versus Delayed, Provisional Eptifibatide in Acute Coronary Syndromes (EARLY ACS) trial. American heart journal. 2013;166(4):723-8. Epub 2013/10/08.

137. Solinas E, Vignali L, Ortolani P, Guastaroba P, Marzocchi A, Manari A, et al. Association of bleeding, mortality and sex in acute coronary syndromes: the missing triangle. Journal of cardiovascular medicine. 2015;16(5):347-54. Epub 2014/09/25.

138. Ndrepepa G, Schulz S, Neumann FJ, Byrne RA, Hoppmann P, Cassese $\mathrm{S}$, et al. Bleeding after percutaneous coronary intervention in women and men matched for age, body mass index, and type of antithrombotic therapy. American heart journal. 2013;166(3):534-40. Epub 2013/09/11.

139. Ndrepepa G, Neumann FJ, Richardt G, Schulz S, Tolg R, Stoyanov KM, et al. Prognostic value of access and non-access sites bleeding after percutaneous coronary intervention. Circulation Cardiovascular interventions. 2013;6(4):354-61. Epub 2013/07/25.

140. Ducrocq G, Schulte PJ, Becker RC, Cannon CP, Harrington RA, Held C, et al. Association of spontaneous and procedure-related bleeds with short- and long-term mortality after acute coronary syndromes: an analysis from the PLATO trial. EuroIntervention : journal of EuroPCR in collaboration with the Working Group on Interventional Cardiology of the European Society of Cardiology. 2015;11(7):737-45. Epub 2014/09/26.

141. Kikkert WJ, Delewi R, Ouweneel DM, van Nes SH, Vis MM, Baan J, Jr., et al. Prognostic value of access site and nonaccess site bleeding after percutaneous coronary intervention: a cohort study in ST-segment elevation myocardial infarction and comprehensive meta-analysis. JACC Cardiovascular interventions. 2014;7(6):622-30. Epub 2014/05/20.

142. Hochholzer W, Wiviott SD, Antman EM, Contant CF, Guo J, Giugliano RP, et al. Predictors of bleeding and time dependence of association of bleeding with mortality: insights from the Trial to Assess Improvement in Therapeutic Outcomes by Optimizing Platelet Inhibition With Prasugrel--Thrombolysis in Myocardial Infarction 38 (TRITON-TIMI 38). Circulation. 2011;123(23):2681-9. Epub 2011/05/25.

143. Rao SV, Eikelboom JA, Granger CB, Harrington RA, Califf RM, Bassand JP. Bleeding and blood transfusion issues in patients with nonST-segment elevation acute coronary syndromes. European heart journal. 2007;28(10):1193-204. Epub 2007/04/26.

144. Akhter N, Milford-Beland S, Roe MT, Piana RN, Kao J, Shroff A. Gender differences among patients with acute coronary syndromes undergoing percutaneous coronary intervention in the American College of Cardiology-National Cardiovascular Data Registry (ACC-NCDR). American heart journal. 2009;157(1):141-8. Epub 2008/12/17.

145. Alexander KP, Chen AY, Roe MT, Newby LK, Gibson CM, AllenLaPointe NM, et al. Excess dosing of antiplatelet and antithrombin agents in the treatment of non-ST-segment elevation acute coronary syndromes. Jama. 2005;294(24):3108-16. Epub 2005/12/29. 
146. Poon S, Goodman SG, Yan RT, Bugiardini R, Bierman AS, Eagle KA, et al. Bridging the gender gap: Insights from a contemporary analysis of sex-related differences in the treatment and outcomes of patients with acute coronary syndromes. American heart journal. 2012;163(1):66-73. Epub 2011/12/17.

147. Newby LK, LaPointe NM, Chen AY, Kramer JM, Hammill BG, DeLong ER, et al. Long-term adherence to evidence-based secondary prevention therapies in coronary artery disease. Circulation. 2006;113(2):203-12. Epub 2006/01/13.

148. Mehran R, Baber U, Steg PG, Ariti C, Weisz G, Witzenbichler B, et al. Cessation of dual antiplatelet treatment and cardiac events after percutaneous coronary intervention (PARIS): 2 year results from a prospective observational study. Lancet. 2013;382(9906):1714-22. Epub 2013/09/06.

149. Wang TY, McCoy L, Henry TD, Effron MB, Messenger JC, Cohen DJ, et al. Early post-discharge bleeding and antiplatelet therapy discontinuation among acute myocardial infarction patients treated with percutaneous coronary intervention. Journal of the American College of Cardiology. 2014;63(16):1700-2. Epub 2014/02/04.

150. Weiss EJ, Bray PF, Tayback M, Schulman SP, Kickler TS, Becker LC, et al. A polymorphism of a platelet glycoprotein receptor as an inherited risk factor for coronary thrombosis. The New England journal of medicine. 1996;334(17):1090-4. Epub 1996/04/25.

151. Alexander KP, Chen AY, Newby LK, Schwartz JB, Redberg RF, Hochman JS, et al. Sex differences in major bleeding with glycoprotein IIb/IIIa inhibitors: results from the CRUSADE (Can Rapid risk stratification of Unstable angina patients Suppress ADverse outcomes with Early implementation of the ACC/AHA guidelines) initiative. Circulation. 2006;114(13):1380-7.

152. Zwierzina WD, Kunz F, Kogelnig R, Herold M. Sex-related differences in platelet aggregation in native whole blood. Thromb Res. 1987;48(2):161-71.

153. Haque SF, Matsubayashi H, Izumi S, Sugi T, Arai T, Kondo A, et al. Sex difference in platelet aggregation detected by new aggregometry using light scattering. Endocr J. 2001;48(1):33-41.

154. Breet NJ, Sluman MA, van Berkel MA, van Werkum JW, Bouman HJ, Harmsze AM, et al. Effect of gender difference on platelet reactivity. Neth Heart J. 2011;19(11):451-7.

155. Koltai K, Papp J, Kenyeres P, Feher G, Tibold A, Alexy T, et al. Gender differences in hemorheological parameters and in in vitro platelet aggregation in acetylsalicylic acid and clopidogrel treated vascular patients. Biorheology. 2014;51(2-3):197-206.

156. Bobbert P, Stellbaum C, Steffens D, Schutte C, Bobbert T, Schultheiss HP, et al. Postmenopausal women have an increased maximal platelet reactivity compared to men despite dual antiplatelet therapy. Blood Coagul Fibrinolysis. 2012;23(8):723-8. 


\section{FACULTY OF MEDICINE AND HEALTH SCIENCES}

Linköping University Medical Dissertations No. 1654, 2019

Division of Cardiovascular Medicine

Department of Medical and Health Sciences

Linköping University

SE-581 83 Linköping, Sweden

www.liu.se 